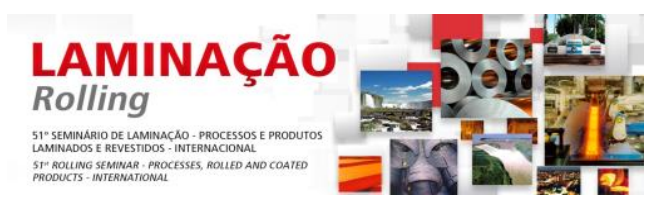

\title{
HIGH CARBON GRADES FOR WIRE ROD LINES THE CORE OF DANIELI TECHNOLOGY
}

Claudio Fabbro' Maicol Cimolino

\begin{abstract}
The increasing demand of wire rod high carbon grades for both small and large sizes are challenging the wire rod producers to enhance new technologies by combining high plant productivity and efficiency of superior quality finished products with extreme process flexibility. The possibility to change process route according to the final application of the rolled steel grade and to simplify production planning is one of the most important keys to success that distinguishes the mill plants developed by Danieli. This paper will focus on the most important metallurgical and process targets and on the in-line heat treatment technologies representing the core of Danieli know-how on high carbon grades production.

Keywords: Wire rod; High carbon steel; High strength wire; Thermomechanical treatment; Rolling optimization.
\end{abstract}

1 Danieli \& C. Officine Meccaniche SpA, Italy. Phone: (+39) 0432.1958111. Email: cl.fabbro@danieli.it.

2 Danieli \& C. Officine Meccaniche SpA, Italy. Phone: (+39) 0432.1958111. Email: m.cimolino@danieli.it.

* Contribuição técnica ao $51^{\circ}$ Seminário de Laminação - Processos e Produtos Laminados e Revestidos, 28 a 31 de outubro de 2014, Foz do Iguaçu, PR, Brasil. 


\section{INTRODUCTION}

Over the last years the production of high carbon wire rod has boosted the research of new and more efficient technologies. This is the result of the increasing world market demand of wire rod to be used in hardware factories for many applications, such as the production of steel cords for reinforcing automobile tires (brass/bronze coated bead wire and cord wire), high strength cables, galvanized wire for suspension bridges and roadways, railroad switches, spring wire, reinforcement strands, rods for the reinforcement of prestressed concrete structures (PC-wire), saw wire to cut silicon wafers for photovoltaic industry, piano wire, etc.

In addition, the increasing request of high productivity plants on the one hand and the necessity to guarantee eco-friendly plants on the other hand are driving the research, even in countries where clear environmental constraints have been only recently introduced.

For this reason the complex process concerning high carbon wire rod production must be regarded as a whole, from steelmaking to billet quality control and conditioning, from in-line heat treatments during hot rolling to final cold drawing process.

Danieli, with all its subsidiaries, has developed a deep multidisciplinary and integrated competence regarding the production of high carbon wire rod in cooperation with some of the biggest special steel producers in the world.

In this article an overview of topics regarding high carbon steel production is reported and a more detailed description about the most innovative in-line technologies for rolling mills is presented.

\section{STEELMAKING QUALITY TARGETS}

The definition of the suitable facilities required for steelmaking is always a delicate issue since many aspects need to be considered: steel process flow (BF, DRI, EAF, HBI, etc.), complete steel grades product mix, existing equipment, layout limitations, final application of the wire rod, etc.

This is the reason why an integrated analysis is required during the dimensioning stage and, even more, during revamping projects. Over the years Danieli Centro Met (DCM) product line has built a solid experience and can fully support customer requests during the delicate and complex stage of plant assessment.

Even if each case must be specifically analysed, the main quality targets for steelmaking in case of high carbon wire rod production can be summarized as follows:

- guaranteeing a high degree of steel cleanliness in terms of endogenous nonmetallic inclusions content;

- avoiding presence of inclusions of exogenous origin;

- guaranteeing a precise content of chemical elements in the heats, especially C, Mn and Si;

- guaranteeing a low segregation and porosity level;

- controlling the nonferrous metal impurities, like $\mathrm{Cr}$ (if not specifically required for the process), $\mathrm{Cu}$ and $\mathrm{Ni}$;

- optimizing carbides promoters addition (e.g. $\mathrm{Cr}$ and $\mathrm{V}$ if specifically required by the process);

* Contribuição técnica ao $51^{\circ}$ Seminário de Laminação - Processos e Produtos Laminados e Revestidos, 28 a 31 de outubro de 2014, Foz do Iguaçu, PR, Brasil. 


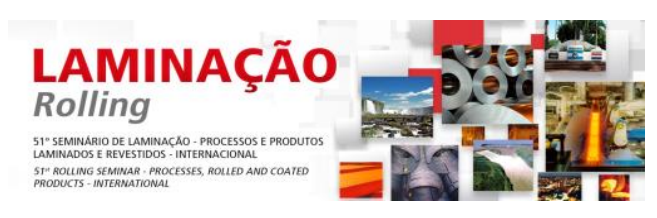

- $\quad$ minimizing content of dangerous impurities like $\mathrm{S}, \mathrm{P}, \mathrm{Sn}, \mathrm{Pb}$, etc.;

- $\quad$ ensuring a proper degassing system $(\mathrm{H}, \mathrm{N})$;

- guaranteeing a good surface quality of the as cast product.

\subsection{Non-metallic Inclusions}

In high carbon grades for wire rod, the presence of non-metallic inclusions is extremely detrimental because of the possible promotion of microscopic cavities or metal matrix discontinuities that in the following rolling and drawing stages can cause wire break. Such inclusions (mainly oxides, silicates, sulphides and nitrides) can originate during different stages of the steel production itself (alloying, desulfurization, dephosphorization) or can have an exogenous origin, with the wear effect caused by the direct contact of liquid steel with the material of the refractory lining.

Apart from the aspects related to overall quantity and distribution, the most important indexes to determine the danger of non-metallic inclusions is their shape and deformability; aluminates are the most harmful ones because of their high melting point and indeformability, while globular manganese sulphides (mostly produced during casting stage) are easily fragmented in fine ductile strings during rolling and can be further deformed in the following drawing stage.

Different methods can be used for the evaluation of non-metallic inclusions, mainly:

- International standard methods, based on specimen-images comparative techniques; these approaches evaluate type, size, shape and frequency of inclusions, but they are by their nature highly subjective.

- Analytical methods identifying the volumetric physical not-uniformity due to the presence of inclusions; these methods are used by some companies (e.g. Bekaert, Michelin) for defining the penalty points during material testing.

- Patented methods developed to evaluate steel contamination; these methods classify the non-metallic inclusions according to their distribution in terms of both type and size; the most well-known of these methods is the Pirelli's.

In order to limit the content of non-metallic inclusions, besides selecting the most suitable refractory material to avoid exogenous inclusions (e.g. basic-based vs acidbased lining of the tundish), one effective strategy is to inoculate rare earth and calcium cored wire ( $\mathrm{SiCa}, \mathrm{FeCa})$ during $\mathrm{LF}$ stage to refine some coarse non-metallic inclusions and to transform some indeformable aluminates (like $\mathrm{MgO} \cdot \mathrm{Al}_{2} \mathrm{O}_{3}, \mathrm{CaO}$ ) into deformable compounds with lower melting point that can be transferred to the slag. This strategy is delicate and implies a dedicated knowledge of liquid steel behaviour.

Moreover, another important aspect is to protect the liquid steel from oxidation during the transfer from the ladle to the tundish and from the tundish to the mould.

\subsection{Chemical Composition}

Ensuring narrow variation of chemical composition within a single heat and within different heats for a specific steel grade is fundamental in order to guarantee the reliability of the overall process of high carbon production. This is particularly true in the case of tire cord grades (e.g. LX70A, SWRH72A, C72D2, C78D2, C82DA, etc.), that require chemical concentration variation typically in the range of $\Delta \mathrm{C}_{\max }=0.01 \%$,

\footnotetext{
* Contribuição técnica ao $51^{\circ}$ Seminário de Laminação - Processos e Produtos Laminados e Revestidos, 28 a 31 de outubro de 2014, Foz do Iguaçu, PR, Brasil.
} 


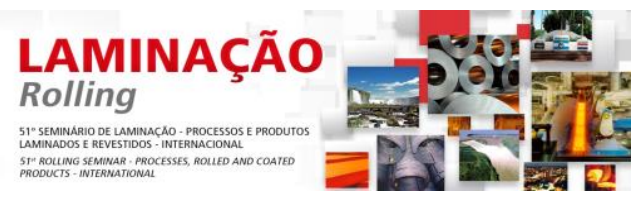

$\Delta \mathrm{Mn}_{\max }=0.03 \%, \Delta \mathrm{Si}_{\max }=0.03 \%$ within a heat, as well as, the lowest levels of armful impurities as phosphorus (typically less than $0.010 \%$ ) and sulfur (typically less than $0.010 \%$ ) that could deeply affect wire ductility during drawing operations. The possibility to use raw materials of different origin (e.g. scrap, DRI, pig iron) can obviously guarantee an optimal reduction of impurities content as $\mathrm{Cr}, \mathrm{Cu}$ and $\mathrm{Ni}$, but in most cases economical evaluations must be done considering the specific material flow resources of the plant.

According to wire rod application, adequate tensile values must be ensured. For this purpose the carbon content is largely the most important factor to control, given its contribute in refining the pearlitic microstructure. Besides the specific range resulting from international standards, there could be some limitations in the maximum carbon content because of the more difficult control of the levels of segregation during the casting phase, that can lead to the unwanted formation of proeutectoid cementite. For this reason, specific casting technologies (e.g. EMS, secondary cooling optimization, dynamic soft reduction, etc.) might be necessary.

An effective way to reduce tensile loss of hot-dip galvanized wire $\left(\sim 450^{\circ} \mathrm{C}\right)$ due to overageing, and to promote recovery of the torsional ductility is increasing silicon content [1], that is a solid solution strengthener of the pearlitic ferrite and influences the ageing response, especially in combination with $\mathrm{Cr}$. The positive $\mathrm{Si}$ effect is particularly evident for those applications where a very high reduction is required during drawing operation. Indeed, the more a specific steel grade is strengthened by applying high drawing reductions, the greater the loss of strength during galvanizing.

Specific alloying addition has been proved to be very effective in guaranteeing appropriate final mechanical properties of the wire rod. For instance, $\mathrm{Cr}$ additions, though generally avoided for tire cords grades (because of the risk of formation of martensitic structures in the final wire rod) [2], are instead typically used in case of PC wire, high strength reinforcing strands, cables for suspension bridges and roadways [3]. For hypereutectoid grades, the increasing of chromium content in combination with carbon will lead to higher strength levels of the patented wire (thanks to $\mathrm{Cr}$ contribute in refining the lamella spacing) and to higher rates of work hardening [4], thus reducing the occurrence of delamination.

Together with $\mathrm{Cr}$, manganese gives a positive hardenability increase, improving the structural homogeneity throughout the cross section. Such effect is due to the Mn influence on the stability of the austenite, whose decomposition (pearlite formation) occurs at lower temperatures, thus refining the pearlite and so increasing the wire strength [5]. Anyhow, for big wire rod diameters and heavy drawing requirements, such element alone is not enough to stabilize austenite, because of the spread of grain size of manganese steels formed by recrystallization between the last rolling stage and before the controlled cooling stage in the conveyor. In fact, the high spread of pearlitic colonies and, in terms of technological properties, of $\Psi$ values (reduction of area after fracture) make chromium addition necessary to stabilize the austenite and to ensure smaller grain sizes.

\footnotetext{
* Contribuição técnica ao $51^{\circ}$ Seminário de Laminação - Processos e Produtos Laminados e Revestidos, 28 a 31 de outubro de 2014, Foz do Iguaçu, PR, Brasil.
} 


\section{$\underset{\text { Rolling }}{\text { LAMIÇÃO }}$}
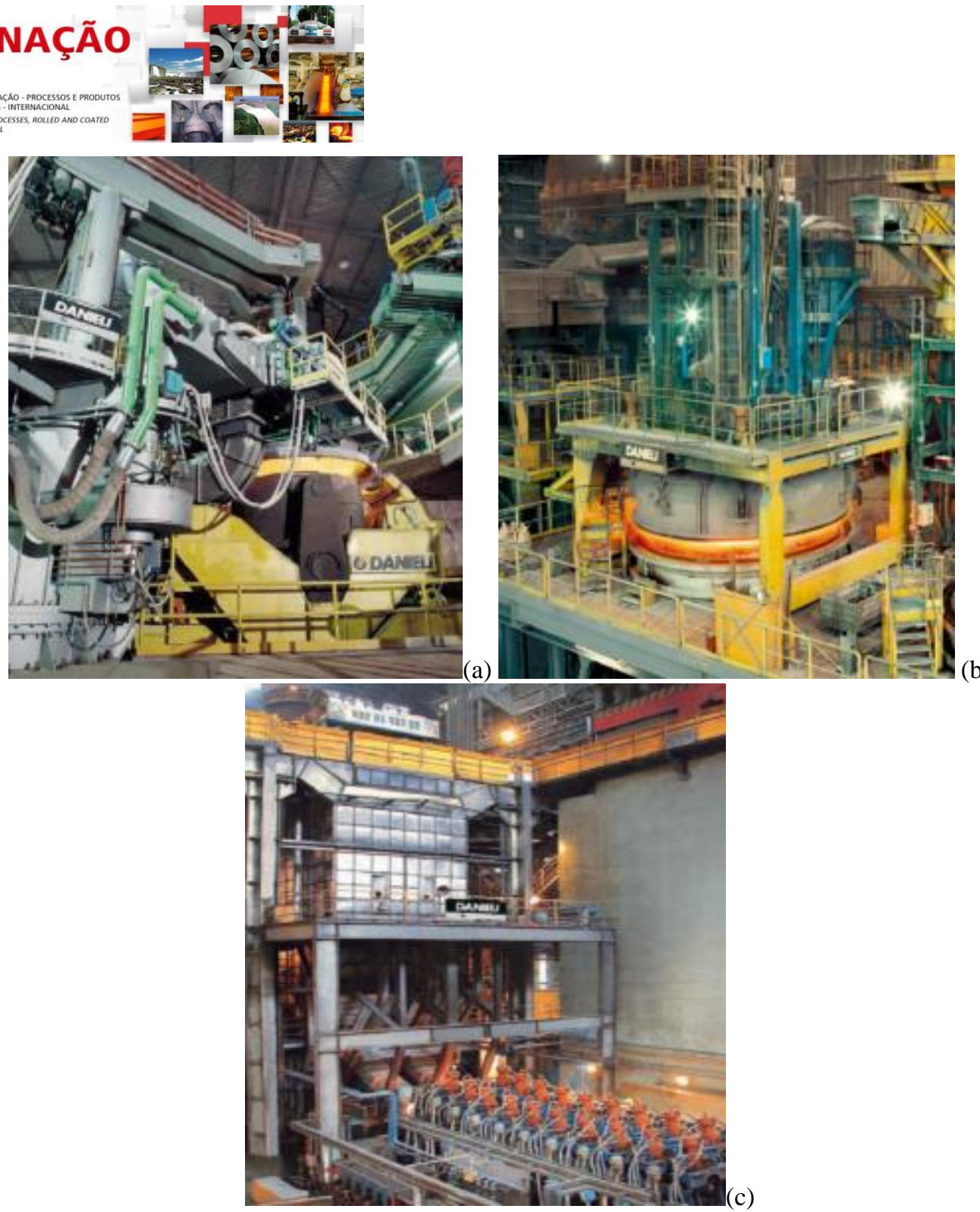

Figure 1. Examples of specific technologies for HC grades: (a) twin-station ladle furnace, (b) VD/VOD station, (c) bloom caster equipped with dynamic soft reduction

Some applications for drawn products require large wire rod with very high mechanical properties as starting feedstock. For this purpose vanadium addition (in some cases up to $0.20 \%$ ) is a very effective method to refine grain size, to enhance hardenability and fatigue resistance, and to increase strength by dispersion hardening (the $\mathrm{V}$ carbides and nitrides form in the pearlitic ferrite, thus retarding the movement of dislocations). With the same mechanical properties, vanadium allows to reduce the carbon content thus enhancing wire weldability, which is further favoured by the $V$ property of not suppressing the ferrite formation, thus delaying the formation of fragile bainitic structures, which are possible cause of the embitterment of the heat-affected zone. Despite these positive properties, $\mathrm{V}$ addition (generally added together with $\mathrm{Cr}$ ) must be limited (typically in the range $0.08 \div 0.12 \%$ ); the reason is not merely economical but also metallurgical, given the tendency of these elements to form segregated microstructures, with local concentrations even more than seven times larger than ladle ones. After the rolling process, the presence of such segregation (dendritic liquation), generally more evident in case of narrow billets, can lead to striated structures, stretched along the

* Contribuição técnica ao $51^{\circ}$ Seminário de Laminação - Processos e Produtos Laminados e Revestidos, 28 a 31 de outubro de 2014, Foz do Iguaçu, PR, Brasil. 


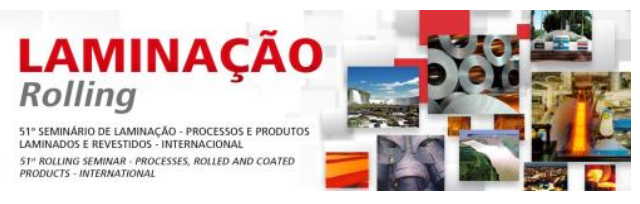

rolling direction and still characterized by carbide liquation. These $\mathrm{Cr} / \mathrm{V}$ liquid microvolumes are detrimental during austenite transformation in the cooling conveyor, because of the risk of forming martensitic quenched structures [6] in specific areas throughout the cross section of the wire rod. Although such microstructures don't generally imply product rejection [7], they are not accepted for the heaviest tire cord applications.

For hypereutectoid grades and especially for big wire rod diameters (for which it is more difficult to guarantee high cooling rates during metallurgical transformation in the cooling conveyor) it is suggested to use carbides (of molybdenum, vanadium) and nitrides (of niobium, molybdenum, titanium, etc.) formers. This enables dispersion hardening and limits the coarse structure-free cementite formation along the pearlitic grain boundaries. Another valid reason for microalloying high carbon grades with vanadium, niobium or titanium is to reduce the Rebinder effect for thick-galvanized wires. Such effect, related to zinc penetration into the grain boundaries, implies wire embrittlement after galvanizing, enhancing the possibility of surface defects formation and torsion tests failure. For such harmful embrittlement, the phosphorus level is another important factor to control: for the high carbon hot-dip galvanized wire, phosphorus has a strong tendency to segregate, forming $\mathrm{Fe}_{3} \mathrm{P}$ compound from cementite, whose plates tends to enlarge.

Boron is another element that can be added in $\mathrm{HC}$ grades by micro-additions. It can be used given its positive effect in containing axial segregation, promoting (with nitrogen) the formation of nitrides and carbonitrides to inhibit aging and quenching, delaying the incubation period for the formation of ferrite, in this way slowing the formation of nucleation centers and decreasing the amount of structure-free ferrite (detrimental problem, e.g. for PC wires) [8].

Although it is possible to identify the specific contribution of each chemical element to $\mathrm{HC}$ wire rod, as mentioned above, the overall performances of wire and wire rod are always the result of the combined effect of all the chemical elements [9], steelmaking strategies and wire rod mill technologies.

\subsection{Gas Content}

The ductility of $\mathrm{HC}$ wire rod and its behavior during following drawing operations are strictly dependent on hydrogen and nitrogen content. For this reason, it is very important to define the quality limits of a steel plant without degassing treatment, that can represent an acceptable solution for PC-wire application (with the necessary precautions in terms of storage and shipping times of the wire rod coils), whereas results generally inadequate for tire cord application.

* Contribuição técnica ao $51^{\circ}$ Seminário de Laminação - Processos e Produtos Laminados e Revestidos, 28 a 31 de outubro de 2014, Foz do Iguaçu, PR, Brasil. 

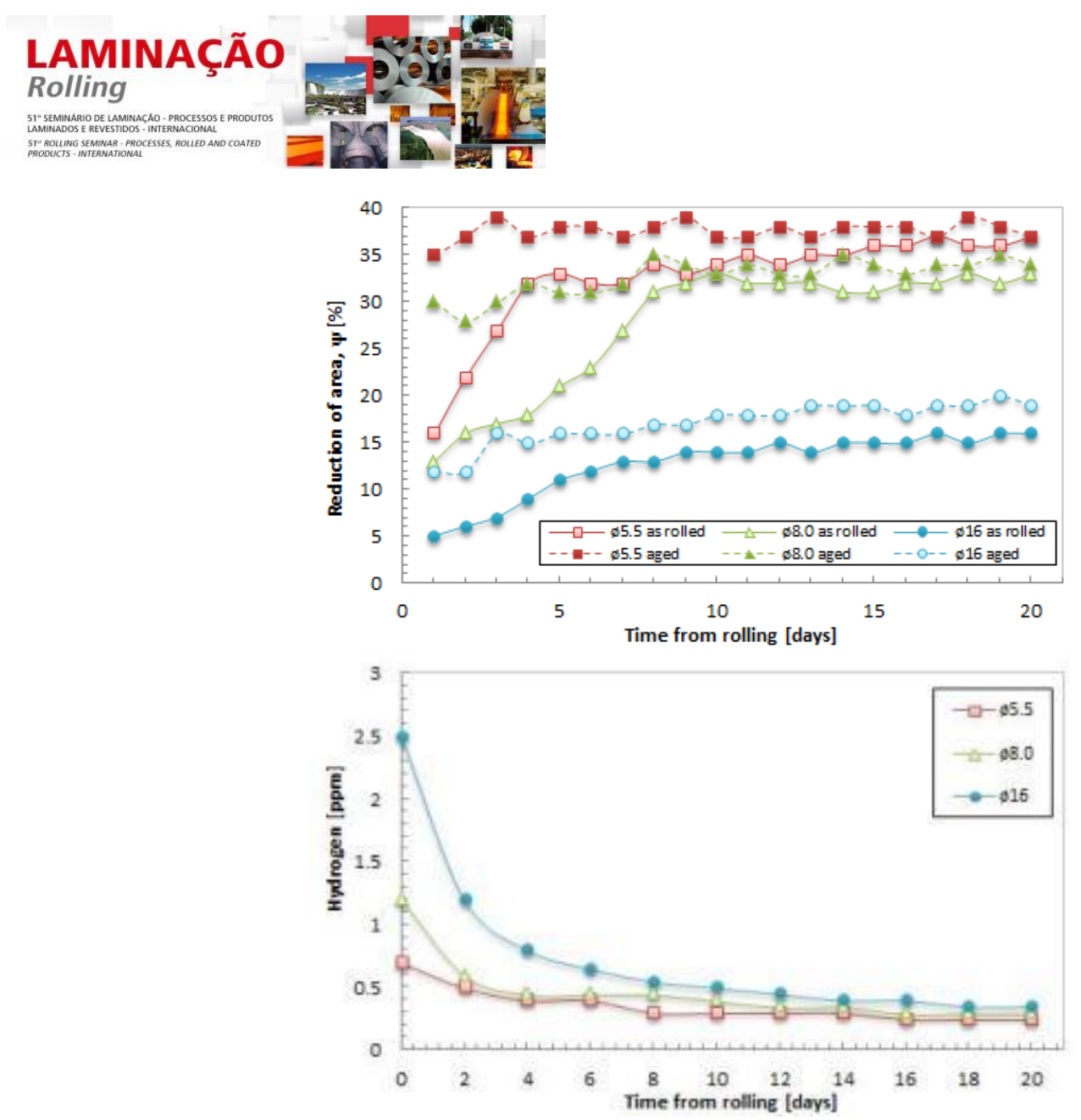

(a)

(b)

Figure 2. Effect of Hydrogen for steel grade SWRH82B for PC wire application: (a) RoA evolution for different sizes (as rolled and artificially aged), (b) Hydrogen evolution for different sizes

For tire cord grades, the lowest level of $\mathrm{H}$ and $\mathrm{N}$ are required in order to enhance wire rod ductility, which is fundamental to achieve an appropriate wire rod breakage frequency during the intensive cold drawing deformations. After the vacuum degassing stage, the typical values are less than $2 \mathrm{ppm}$ for hydrogen and less than $60 \mathrm{ppm}$ for nitrogen. Particularly hydrogen can be responsible of brittle fractures phenomena because it can diffuse very easily thanks to the small dimensions of its atom, thus reducing the cohesive strength of steel structure. Hydrogen can become even more dangerous when, passing from the atomic to the molecular stage, it causes local huge hydrostatic stresses. This phenomenon may be such as to cause the sharp fragile fracture of the wire rod even just after rolling.

The effect of nitrogen during the cold drawing stage is well-known: as a small interstitial solute $\mathrm{N}$, whom solubility is even higher than $\mathrm{C}$, can diffuse to dislocations limiting their mobility. Such behaviour is the "conventional" strain ageing and is generally controlled through micro-addition of carbonitrides formers (e.g. Ti, V, Nb, B), that can limit also the static ageing.

Hydrogen, instead, is responsible for the so called "reverse" ageing at room temperature after the rolling stage. Such behaviour implies the increase of wire rod necking over time due to the release of $\mathrm{H}$ from the wire rod. It has been demonstrated that hydrogen release is controlled by a trap-controlled diffusion phenomenon [10]; from the

* Contribuição técnica ao $51^{\circ}$ Seminário de Laminação - Processos e Produtos Laminados e Revestidos, 28 a 31 de outubro de 2014, Foz do Iguaçu, PR, Brasil. 


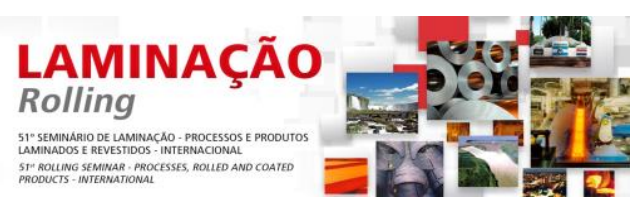

technological point of view, this implies that hydrogen concentration over time depends on the wire rod diameter. In Figure 2 (a) and (b), the data for grade SWRH82B taken from a Danieli Morgårdshammar rolling mill are reported, showing the mentioned dependence (note: the data are referred to a steel grade treated in a vacuum degassing station).

Similar studies have been carried out in other mills [11], with comparable results. In Figure 2 (a) it is important to note the different time required to reach the fully aged value, which increases with wire rod size. In the mills for HC production, this leads to the definition of specific procedures for storage and shipping of the coils to provide an adequate material to hardware factories. To test and qualify the wire rod product in the fully aged stage, more than two weeks are required for the larger products; for the rolling mill practice it is not possible to wait so long; therefore artificial ageing is advisable. In Figure 2 (a), the $\Psi$ trends for "as rolled" and artificially aged ( 1 hour at $150^{\circ} \mathrm{C}$ ) wire rods are reported. It is important to note that, performing the same test in terms of wire rod tensile evolution against time, no specific dependence is noted.

In some plants, where it is possible to produce wire rod for PC wires, reinforcing strands and cables for construction purposes, but not tire cord grades, the vacuum degassing station is not installed. This condition exacerbates the above-mentioned problems, because the content of $\mathrm{H}$, that during steelmaking can be originated e.g. by wet lime or moist ferroalloys, remains uncontrolled. As a consequence the appearance of uncontrolled fragile fractures is much more frequent, especially for the larger sizes. These problems are evident not only in the $\mathrm{HC}$ wire rod, but also in the final PC wires [12].

\subsection{Segregation}

The control of segregation levels in the starting billet/bloom represents one of the most important aspects to guarantee reliable performances in the final drawn wire, as explained in the previous paragraphs. Even in this case a broader economic assessment is required to make the correct technological choice, considering the whole steel grades to be produced and the size product mix.

In order to guarantee an adequate segregation level of the wire rod (e.g. by NFA evaluation), the casting stage becomes essential to produce billets/blooms characterized by the minimum occurrence of columnar crystal and the maximum incidence of regions with equiaxial crystals. Any dendritic segregation can lead to the formation of segregation bands that can still be present even after rolling and drawing, limiting the reliability of wire performances.

Moreover, even micro-segregation can lead to the formation of martensitic structures in the central area of the wire rod, increasing wire breakage risk. It is important to note that the presence of such martensitic structures does not necessarily imply the product rejection, because hardware companies' specifications define their maximum permissible length.

In order to ensure suitable segregation levels and, more in general, to enhance the as cast product quality, the following strategies could be adopted:

- ensuring proper control of superheat;

- controlling casting speed and temperature profile;

* Contribuição técnica ao $51^{\circ}$ Seminário de Laminação - Processos e Produtos Laminados e Revestidos, 28 a 31 de outubro de 2014, Foz do Iguaçu, PR, Brasil. 


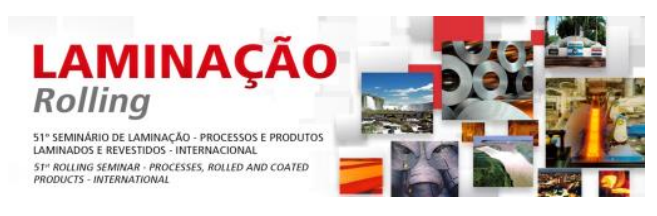

- installing mould and eventually final EMS: fluid-dynamics studies taking into account the electromagnetic forces of the EMS mould enable the improvement of internal quality of cast products by optimizing EMS position and its electrical parameters;

- selecting the appropriate dynamic controlled secondary cooling system: technology (water or air-mist), nozzles arrangement, control strategy and flow rate and pressure operative conditions are all crucial evaluations to be done;

- applying dynamic soft reduction technology and, at the same time, using appropriate crack-index control strategy.

It is easy to understand how only a sophisticated automation system can guarantee the complete control of the critical casting stage, thus ensuring good internal quality of the billets/blooms. Moreover, during the dimensioning stage the feasibility and the benefits of a specific technology (e.g. dynamic soft reduction) must be considered in relation with the overall process flow, the feedstock dimensions, the availability of conditioning lines and the rolling strategies (see also next paragraphs).

\section{BILLET SELECTION AND PREPARATION}

The definition of the most appropriate $\mathrm{HC}$ billet/bloom size and required surface quality is still a hotly debated topic. As a matter of fact, considering the top ranking list of the worldwide best HC producers, different technologies are used. Danieli has an extensive experience on this topic, thanks to the longstanding competence of its subsidiaries and the fruitful cooperation with some of these renowned $\mathrm{HC}$ producers.

In many cases, the process route is determined by logistic strategies and economical evaluations. Only in specific circumstances, indeed, the market demand of superior quality $\mathrm{HC}$ wire rod can justify higher CapEx and OpEx. By way of example, in Table 1 specific process routes used by some of worldwide best wire rod producers for tire cord are reported.

As reported in Table I, some producers have multiple possibilities in terms of starting feedstock: small billets, blooms and even ingots. The intimate reasons for these different solutions are the core of the know-how developed by collaboration between the customer and Danieli. Anyhow the general considerations can be summarized as follows:

- the initial investment increases with feedstock size: for the biggest bloom or for the ingots, multiple reheating and rolling equipment is required, as well as additional storage and conditioning areas. For medium size blooms, a free roughing mill or a reversible mill is generally required;

- the transformation cost from cast product to final wire rod increases with feedstock size (approximately $40 \div 55 \$$ ton higher cost compared with single heat technologies for a WE producer), because of the higher energy consumption, the additional equipment consumable and maintenance, the supplementary manpower, the extra material handling;

- the material yield depends on available casting technology and on the possible need of conditioning (e.g. grinding, scarfing);

\footnotetext{
* Contribuição técnica ao $51^{\circ}$ Seminário de Laminação - Processos e Produtos Laminados e Revestidos, 28 a 31 de outubro de 2014, Foz do Iguaçu, PR, Brasil.
} 


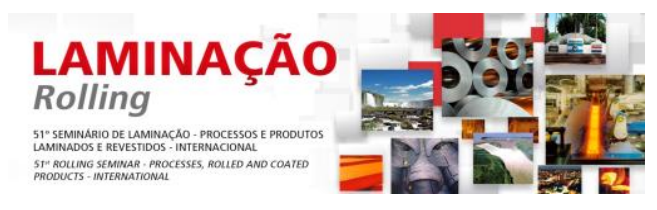

- the flexibility to feed other rolling lines (e.g. SBQ mills) is maximum for the biggest feedstock, because for large products adequate reduction ratios are required to ensure acceptable internal quality;

- the segregation of as-cast product depends on available casting technology; the best level is generally reached for larger blooms with EMS (mould and eventually strand) and DSRC (Dynamic Soft Reduction Control);

- the decarburization level depends on the specific reheating technologies available, but generally for the big blooms longer soaking times are required, thus creating deeper decarburization. This is even more significant for double reheating and rolling process: for the most critical steel grades specific billet preparation strategies are commonly used, like complete grinding or scarfing;

- the best control of bloom internal cleanness is generally reached for the large blooms, in other conditions being equal, because of the higher radius of CCM, the lower casting speed and so the easier inclusions floatation to the meniscus in the mould.

Table 1. Examples of process routes used to produce $\mathrm{HC}$ wire rod for tire cord

\begin{tabular}{|c|c|c|c|c|c|c|c|c|c|}
\hline Customer \# & \multicolumn{2}{|c|}{ STARTING BLOOM } & \multicolumn{2}{|c|}{ INTERMEDIATE BLOOM } & \multirow{2}{*}{$\frac{\mathbf{1}^{\text {st }} \mathbf{R R}}{[-]}$} & \multicolumn{2}{|c|}{ FINALE SIZE } & \multirow{2}{*}{$\frac{2^{\text {nd }} \mathbf{R R}}{[-]}$} & \multirow{2}{*}{$\begin{array}{c}\text { TOTAL RR } \\
{[-]}\end{array}$} \\
\hline$[-]$ & {$[\mathrm{mm}]$} & [inch] & {$[\mathrm{mm}]$} & [inch] & & {$[\mathrm{mm}]$} & [inch] & & \\
\hline 1 & $140 \times 140$ & $5-33 / 64 \times 5-33 / 64$ & - & - & - & $\varnothing 5.5$ & $\varnothing 7 / 32$ & - & $1: 825$ \\
\hline 2 & $230 \times 280$ & $9-1 / 16 \times 11-1 / 32$ & - & - & - & $\varnothing 5.5$ & $\varnothing 7 / 32$ & - & $1: 2711$ \\
\hline 2 & $355 \times 750$ & $13-31 / 32 \times 29-17 / 32$ & $180 \times 180$ & $7-3 / 32 \times 7-3 / 32$ & $1: 8$ & $\varnothing 5.5$ & $\varnothing 7 / 32$ & $1: 1364$ & $1: 11207$ \\
\hline 3 & $140 \times 140$ & $5-33 / 64 \times 5-33 / 64$ & - & - & - & $\varnothing 5.5$ & $\varnothing 7 / 32$ & - & $1: 825$ \\
\hline 3 & $300 \times 250$ & $11-13 / 16$ x 9-27/32 & - & - & - & $\varnothing 5.5$ & $\varnothing 7 / 32$ & - & $1: 3157$ \\
\hline 4 & $240 \times 240$ & $9-29 / 64 \times 9-29 / 64$ & - & - & - & $\varnothing 5.5$ & $\emptyset 7 / 32$ & - & $1: 2424$ \\
\hline 4 & $200 \times 200$ & $7-7 / 8 \times 7-7 / 8$ & - & - & - & $\varnothing 5.5$ & $\varnothing 7 / 32$ & - & $1: 1684$ \\
\hline 4 & $200 \times 280$ & $7-7 / 8 \times 11-1 / 32$ & - & - & - & $\varnothing 5.5$ & $\emptyset 7 / 32$ & - & $1: 2357$ \\
\hline 5 & $280 \times 380$ & $11-1 / 32 \times 14-61 / 64$ & $155 \times 155$ & $6-7 / 64 \times 6-7 / 64$ & $1: 4$ & $\varnothing 5.5$ & $\varnothing 7 / 32$ & $1: 1011$ & $1: 4478$ \\
\hline 6 & $150 \times 150$ & $5-29 / 32 \times 5-29 / 32$ & - & - & - & $\varnothing 5.5$ & $\varnothing 7 / 32$ & - & $1: 947$ \\
\hline
\end{tabular}

Billet conditioning is a further crucial aspect for $\mathrm{HC}$ production because it represents the link between the casting and the rolling technologies. Billet quality inspection rules must be specified to define if the as-cast billet can be directly transferred to rolling mill or if conditioning is required, thus controlling the risk of product rejection.

The choice whether to foresee or not inspection and conditioning technologies in an integrated plant (CCM and rolling mill) is not as simple as it can appear; such technologies, indeed, have a relative high investment cost, so a deep knowledge of the specific upstream and downstream processes is required [13]. Danieli Centro Maskin (DCMK) product line boasts a long-time competence such to be able to fully support its customers' demands. The target of these conditioning lines is to guarantee high surface finish of as-cast product (e.g. absence of laps and bleeds, control of decarburization

* Contribuição técnica ao $51^{\circ}$ Seminário de Laminação - Processos e Produtos Laminados e Revestidos, 28 a 31 de outubro de 2014, Foz do Iguaçu, PR, Brasil. 


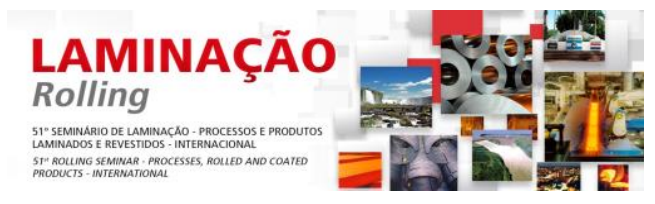

depth) on the one hand, and to increase overall production capacity (minimizing final product rejection) on the other hand, while setting appropriate safety and environmental standards for both noise and fume dust collection control.

Billet geometrical and surface quality conditions must be detected in order to operate with the best grinding mode:

- skin grinding (grinding of the whole surface);

- spot grinding (partial grinding on selected areas only);

- corner grinding;

- pattern grinding (grinding on pre-defined areas of the product surface according to steel grade and casting sequence).

An extremely accurate grinding pressure and power control must guarantee constant and minimum removal depth and high production rates, thus minimizing material yield loss.

Even in some of plants reported in Table 1, billet preparation is not always foreseen. It is therefore easy to understand how important is to know the quality limits of the technological solution for the final wire rod, considering the whole list of steel grades to be produced.

\section{REHEATING FURNACE PRACTICE}

Different types of reheating furnaces (RHF) are used by $\mathrm{HC}$ producers and, besides the specific technology available and mechanical limitations, the reheating pattern is set according to:

- target productivity;

- steel grades production schedule optimization;

- rolling mill configuration (continuous or not);

- any rolling mill limitation: e.g. stands overload in case of too low rolling temperature;

- maximum allowed decarburization depth for the final product;

- required billet surface/core temperature uniformity;

- billet origin and surface finish: CCM or pre-rolled billet, rough or conditioned billet;

- RHF kick-in practice: cold charge, warm charge, mixed charge;

- possibility to control the oxidizing atmosphere, especially in the high temperatures soaking zones (detrimental for decarburization phenomena)

- specific environmental, safety and economical limitations.

Pusher type furnaces are generally avoided for $\mathrm{HC}$ grades (at least for those grades with high quality requirements), because of the lower billet surface quality, the worse temperature uniformity and the longer soaking times (deeper decarburization). Walkinghearth (especially with billet rotating devices) and walking-beam furnaces are instead extensively used, for two reasons mainly: on the one hand this kind of furnace can guarantee better billet quality in terms of surface finish and temperature uniformity; on the other hand, an enhanced process flexibility (change of steel grades, reheating pattern, productivity) can be reached.

Such evaluations must be taken into account from the first stages of line dimensioning, especially for revamping projects, where the existing equipment can force to use operational practices that are not optimal. The RHF efficiency is primarily determined by

* Contribuição técnica ao $51^{\circ}$ Seminário de Laminação - Processos e Produtos Laminados e Revestidos, 28 a 31 de outubro de 2014, Foz do Iguaçu, PR, Brasil. 


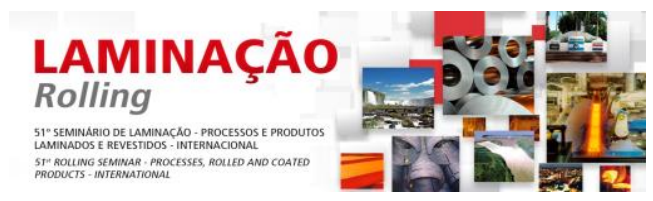

the quality of the project and, therefore, the know-how of the manufacturer. Danieli Centro Combustion \& Olivotto Ferrè (DCC \& DFO) product line is constantly increasing its efforts to improve equipment efficiency and profitability through a consolidated dimensioning approach starting from sophisticated engineering evaluations.

In order to outline the type of combustion system and optimal heating elements, thermal and fluidodynamic calculation are required to define on the one hand the thermal zones in terms of number and extension, and, on the other hand, the proper room geometry and pressure control system. In order to increase the RHF efficiency different aspects must be considered, some of them related to burners' control, as completing combustion with minimum excess of air and ensuring the temperature uniformity in the active volume by the dragging effect of the high speed combustion gas. Furthermore, since operating at correct project temperatures and productivities is one key factor to guarantee high RHF efficiency, it is also fundamental to contain and recovery heat losses, such as the dispersion through the fumes (used to preheat the combustion air), through the walls (related to thermal insulation) and through the openings (monitored by the seal maintenance, the control of the internal pressure and the management of chimney draught) [14].

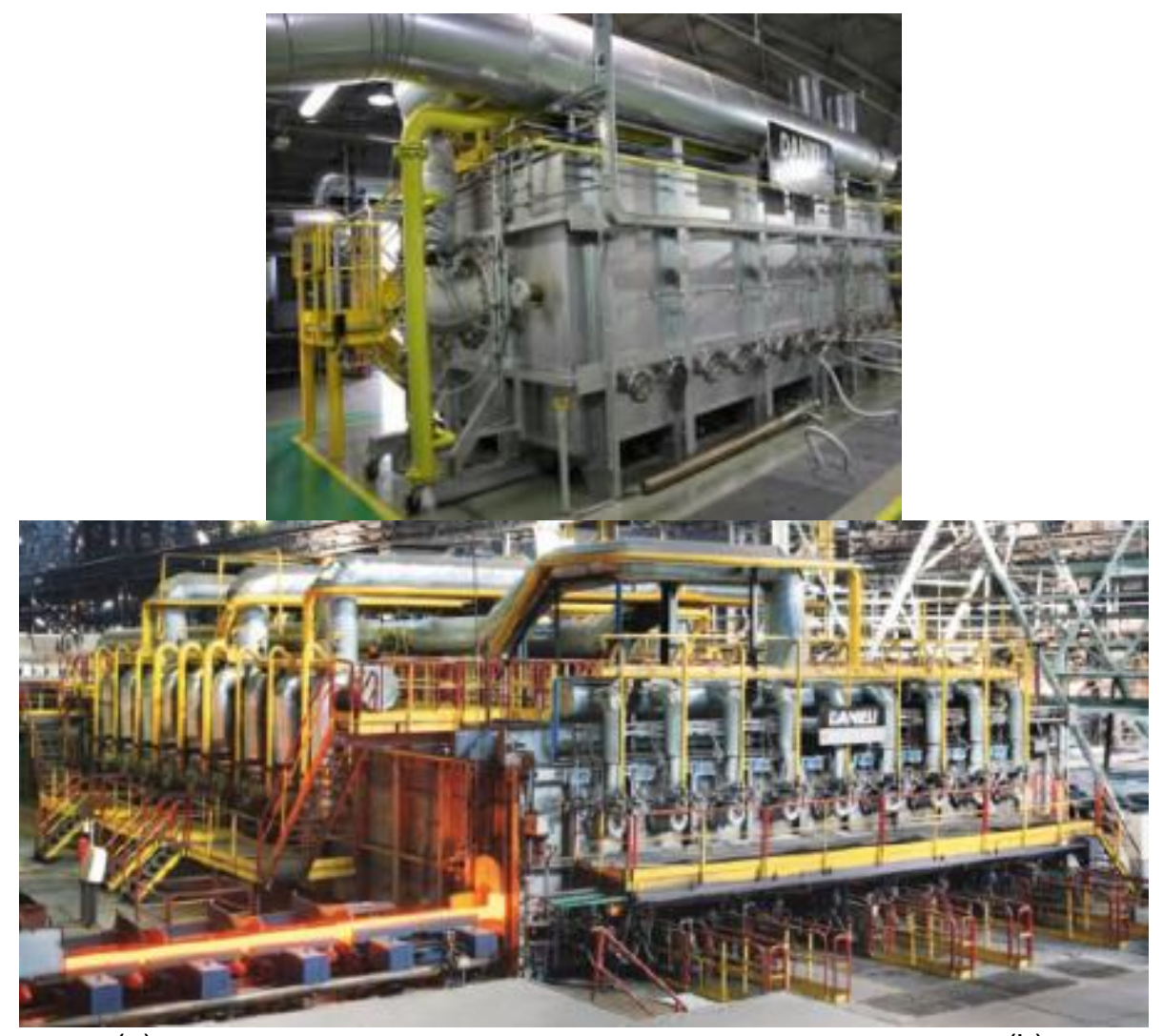

(a)

(b)

Figure 3. (a) pilot plant at Danieli Centro Combustion Research Center (Savona, Italy), (b) plant walkinghearth RHF

To optimize reheating pattern is even more important for the specific case of $\mathrm{HC}$ billets, given by their quality requirements and susceptibility to decarburization. Compared with the traditional amplitude modulated systems, the new generation of pulse firing control

\footnotetext{
* Contribuição técnica ao $51^{\circ}$ Seminário de Laminação - Processos e Produtos Laminados e Revestidos, 28 a 31 de outubro de 2014, Foz do Iguaçu, PR, Brasil.
} 


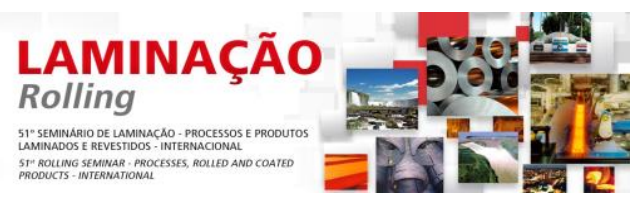

systems (PHL) can give big benefits in terms of both process and productivity: the high speed burners operate close to maximum efficiency, achieving maximum heat transfer with minimum power consumption, increasing thermal uniformity, improving regulating capacity and reducing NOx emission, thanks to the more complete gas mixing and the lower flame peak temperature. In this way operational cost can be reduced but also, more important from the quality point of view, a better scale control is guaranteed.

The development of mathematical models able to reproduce kinetics of combustion and thermal phenomena is just the first step to the proper dimensioning of the RHF. Experimental setup by pilot plants can indeed allow to optimize specific reheating patterns or new heating technologies (Figure 3).

One of the most critical aspects to be considered for the reheating of tire cord grades is to limit the head-to-tail temperature drop due to the rolling time in a continuous mill. This problem is particularly acute for those special steel mills with high productivity requirements, where the mill configuration and billet dimension/weight are set to reach plant full capacity. For those billets, relatively heavy, the pure rolling time is quite low for the products rolled at full productivity, while it is longer for the smallest products because, even if rolled at the highest speeds, their productivity is the lowest. This means that the head-to-tail temperature drop at the continuous mill entry is the highest one for wire rods as $5.5 \mathrm{~mm}$ (typical size for tire cord application). This problem can be limited by a proper control of the RHF, setting the heating pattern in the various sections so that it is possible to partially compensate the natural temperature loss in the billet tail.

\section{ROLLING MILL KEY EQUIPMENT}

Since the beginning of the 2000s the technologies and methods used to produce wire rod have undergone significant changes. Machine builders have been racing to provide the market with innovative and reliable solutions backed by continuous research and development. The use of advanced engineering materials and enhanced automation systems is the firm point of wire rod producers that want to optimize their investments: together with the mill equipment suppliers, they sense the urgency to find innovative solutions to improve the quality of their products with considerable energy savings and enhanced performance [15]. If this argument is generally true for special steel wire rod mills, it is an absolute priority in the case of $\mathrm{HC}$ grades, where rolling mill optimization, operational flexibility and process reliability play a fundamental role.

In order to improve the finished product quality (in terms of size tolerances, mechanical properties and surface finishing), a reliable and dedicated automation system is required. Different automation systems are implemented in modern rolling mills to control thickness/section, the angular speed of the rolls, the tension between the stands and the related temperatures. Innovative technologies and processes have been developed over the years to reduce production costs and optimize mill efficiency thanks to very quick production changes.

Wire rod producers are currently choosing to install ultra-modern mechanical equipment and electronic systems in their rolling mills so as to be able to switch from a roll pass design with many rolling families to a single-family pass design for the whole mill. This requires the use of sizing machines located at the end of the finishing mill and allowing rolling section changes.

\footnotetext{
* Contribuição técnica ao $51^{\circ}$ Seminário de Laminação - Processos e Produtos Laminados e Revestidos, 28 a 31 de outubro de 2014, Foz do Iguaçu, PR, Brasil.
} 


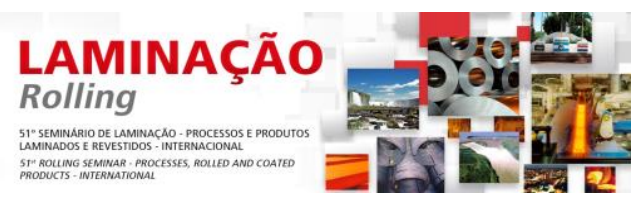

Danieli Morgårdshammar (DMH) has made great strides in helping and supporting its customers, and/or prospective customers, reach the standards set by world markets [16]. For HC grades, specific thermomechanical processes and automated control systems have been developed to enhance wire rod technological properties, tolerances and surface quality, as well as to reduce production cost and environmental impact, thus improving the overall plant competitiveness.

\subsection{Mill Configuration}

The rolling stands represent the core of the rolling process and their configuration has to be properly chosen according the dimensioning technological parameters: steel grades product mix, rolled sizes, minimum and maximum productivity, minimum and maximum rolling time, required biting speed, required shears configuration, available upstream and downstream facilities, media availability and cost, layout limitation, etc.

It is easy to understand to which extent an inappropriate mill configuration can affect the entire rolling process. HC producers, and in a broader sense special steel producers, feel the need of more and more process flexibility in terms of steel grade to be produced, rolling strategy to apply, and size changing quickness. This has become even more stringent due to the economic crisis, that has forced steel producers to accept even orders as small as few billets only, with consequent adoption of production planning strategies more typical of stainless steel producers [17]. In a modern European special steel mill, in fact, it is not unusual to have more than 250 size changes in a multiline rolling mill (e.g. bar, bar in coil, wire rod).

For this reason, the possibility to reduce changing time and to simplify roll pass design is a priority. For high productivity wire rod mills, having a high-speed free roughing mill with the typical $\mathrm{H} / \mathrm{V}$ configuration can be a good solution to manage both the full-productivity big sizes (slow final rolling speeds, elevated mill biting speeds, short rolling times) and the high-speed small ones (low productivity, elevated rolling times, low mill biting speeds); in this way the minimum biting speed at the continuous mill entry will be high enough even for critical sizes and grades as tire cord. Such solution, anyhow, must be carefully analysed since it implies a layout extension, thus affecting the required investment.

In order to feed the mill with a billet characterized by a proper surface quality, a part from the above mentioned aspects on billet preparation and RHF practice, in-line surface cleaning is required. For $\mathrm{HC}$ grades this is a very important issue: a perfectly clean surface must be ensured in order to avoid irreversible surface defects in the following rolling stages ("rolled-in" scale). For this reason, primary scale removal is performed at the furnace exit by a high water pressure descaler in very short times (elevated billets speeds), to avoid detrimental surface overcooling.

The optimal shear sequence and position depend basically on the steel grade product mix; generally $\mathrm{HC}$ grades are not the most critical ones from the shear sequence point of view, but they are often the dimensioning ones for the cutting force required, especially when low temperature RHF practices or low temperature rolling conditions are adopted.

Even the stands themselves must ensure the appropriate stiffness, with high axial and radial rigidity, to support the high rolling loads of $\mathrm{HC}$ grades. As a consequence the best compromise between different aspects must be found:

* Contribuição técnica ao $51^{\circ}$ Seminário de Laminação - Processos e Produtos Laminados e Revestidos, 28 a 31 de outubro de 2014, Foz do Iguaçu, PR, Brasil. 


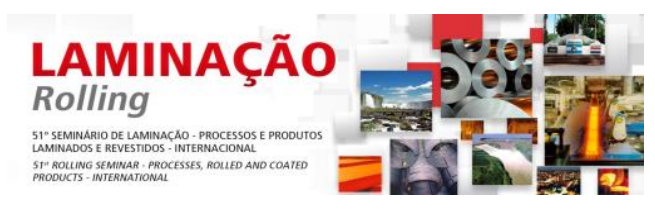

- stand stiffness,

- changing time,

- buildings costs (layout compactness),

- required civil works and foundations,

- machine cost,

- erection and start up time,

- electric power consumption,

- spare part costs,

- operational costs.

In order to minimize cobble risk, stand selection is fundamental. From this point of view, the SHSplus stands represent an excellent solution, given the "pipe-less concept" applied: most of external tubes for media connection are eliminated (water/air-oil), while almost all the connections from the drive side to the operator side are moved into the container. This means that the assembly time for hoses is much shorter and, in case of cobble, the risk of damaging the hoses is drastically reduced.

\subsection{In-line Induction Furnaces}

The temperature drop between the head and the tail of the bar (thermal cone) can only partially be compensated by RHF setup. Such problem becomes very serious when heavy billets are used for small product like $\varnothing 5.5 \mathrm{~mm}$ (e.g. tire cord applications) in fullcontinuous mills layouts, and can determine very low biting speeds at the first stand entry (large rolling times), especially if there is a significant limitation for the maximum rolling speed.

A layout with a high-speed free-roughing mill and a sequence of retaining hoods at the entry side of the continuous mill can help limit such problem, as already explained. Anyhow, this cannot fully compensate the thermal cone caused by the high rolling times; by contrast, the installation of an induction furnace in this area can fully eliminate headtail temperature drop and, if required, can also guarantee an additional temperature boostering. Such devices, now developed by Danieli Automation (DA), can guarantee a constant temperature at continuous mill entry and, as a consequence, at finishing mill exit for the whole length of the coil. This can significantly improve wire rod final technological properties, in terms of constancy and reliability, for those grades, like high carbon ones, that are very sensitive to temperature fluctuations.

\subsection{WRB - Wire Rod Blocks}

The latest generation of high speed pre-finishing/finishing and sizing blocks featuring advanced design and accurate manufacturing enables production of prime quality wire rod at elevated finishing speeds. This is very important for $\mathrm{HC}$ grades and particularly for the smallest sizes, in order to reduce the pure rolling time.

As explained for the stands, when rolling $\mathrm{HC}$ grades the blocks must withstand high rolling loads and transmit high rolling torques given their sturdy design and heavy-duty construction. This is an absolute priority because $\mathrm{HC}$ grades are very sensitive to improper rolling temperature that could be forced by any rolling block limitation. Moreover, as the possibility to obtain tight dimensional tolerances is another

\footnotetext{
* Contribuição técnica ao $51^{\circ}$ Seminário de Laminação - Processos e Produtos Laminados e Revestidos, 28 a 31 de outubro de 2014, Foz do Iguaçu, PR, Brasil.
} 


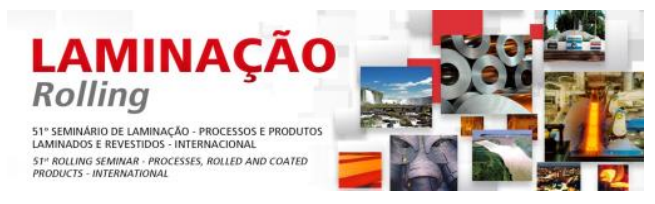

fundamental aspect for both big and small sizes of $\mathrm{HC}$ grades, reducing and sizing blocks as TMB $^{\circledR}$-Twin Module Block represent the best answer to the growing demand of wire rod users.

Apart from the benefits achieved in terms of operational cost, plant efficiency and material yield thanks to application of the "single pass family" concept (all the products are finished on the $\mathrm{TMB}^{\circledR}$ ), the improvements resulting from the use of these machines for high carbon grades are primarily reflected on the quality of the material itself. The reasons are multiple:

- thanks to the optimized rolling sequence and tension optimization (also multidrive configuration can be used), it is possible to achieve tight size tolerances in terms of both absolute values (for smaller sizes down to $\pm 0.075 \mathrm{~mm}$ with $50 \%$ of ovality) and reliability/repeatability along the coil and between different coils;

- small sizes can be produced with superior rolling speeds, thus reducing pure rolling times and head-to-tail temperature drop;

- big sizes have a better coil tail shape, thanks to the small distance between sizing block and loop laying head and the shorter water cooling line after the sizing block;

- the bar untreated (not water cooled) length will be lower;

- internal quality is ensured thanks to the proper reduction of area achieved in the sizing block;

- thermomechanical treatments can be applied guaranteeing a proper grain size control;

- the technological reduction in cross-section at breaking point $(Z)$ is increased;

- the thermal profile will be more easily controlled thanks to the multi-stage rolling and cooling sequence, thus avoiding excessive temperature increase in the fast finishing blocks (see also Figure 4);

- a lower spread of final technological properties can be achieved;

- the scale appearance is drastically improved (typical requirement of $\mathrm{HC}$ wire rod users), thanks to the reduced cooling necessary after the last rolling sequence;

- the decarburization layer is thinner and more uniformly distributed along the perimeter of the wire rod [18].

Even today there are still those who argue about the improper quality of wire rod produced by means of sizing blocks. These arguments stem from the phenomena of abnormal grain growth occurred in the past (not in DMH mills) due to the improper reduction foreseen for those blocks. Such problems were fixed and solved more than 15 years ago with the definition of the modern reducing and sizing blocks, where:

- the first 2 passes, with an oval-round sequence, guarantee the proper reduction avoiding any abnormal grain growth and create the ideal condition for low temperature rolling;

- the last 2 passes, with a round-round sequence, allow to achieve the superior size tolerance previously mentioned.

The total reduction of the sizing group is well above the critical reduction for the whole range of product mix; this is the reason why the majority of the most renowned special steel producers in the world apply such technology.

\footnotetext{
* Contribuição técnica ao $51^{\circ}$ Seminário de Laminação - Processos e Produtos Laminados e Revestidos, 28 a 31 de outubro de 2014, Foz do Iguaçu, PR, Brasil.
} 

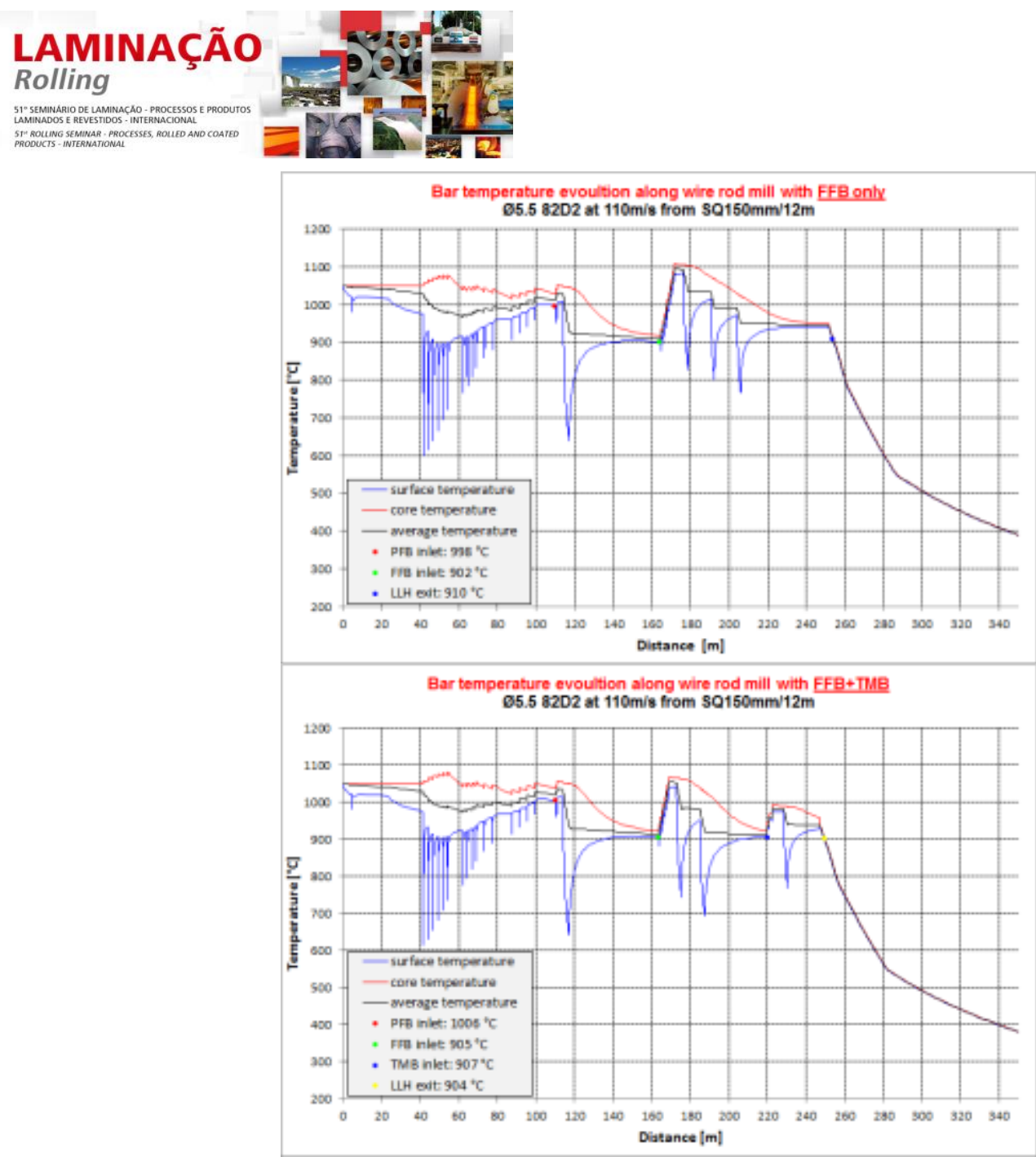

(a)

Figure 4. Bar temperature evolution for $\varnothing 5.5 \mathrm{~mm}$ grade $82 \mathrm{D} 2$ along two real $\mathrm{DMH}$ wire rod mills: (a) layout with FFB only, (b) layout with FFB and $\mathrm{TMB}^{\circledR}$

\subsection{HSS - High Speed Shear}

Head and tail trimming is a fundamental operation in wire rod production. In conventional wire rod mills coil head and tail trimming is manually performed in the coil handling line (trimming station) involving at least two operators per shift. In some countries such operation is performed along the cooling conveyor, typically by three operators per shift (excluding the one working in the reforming pit area), with the obvious consequences in terms of safety, manpower cost and process reliability.

* Contribuição técnica ao $51^{\circ}$ Seminário de Laminação - Processos e Produtos Laminados e Revestidos, 28 a 31 de outubro de 2014, Foz do Iguaçu, PR, Brasil. 

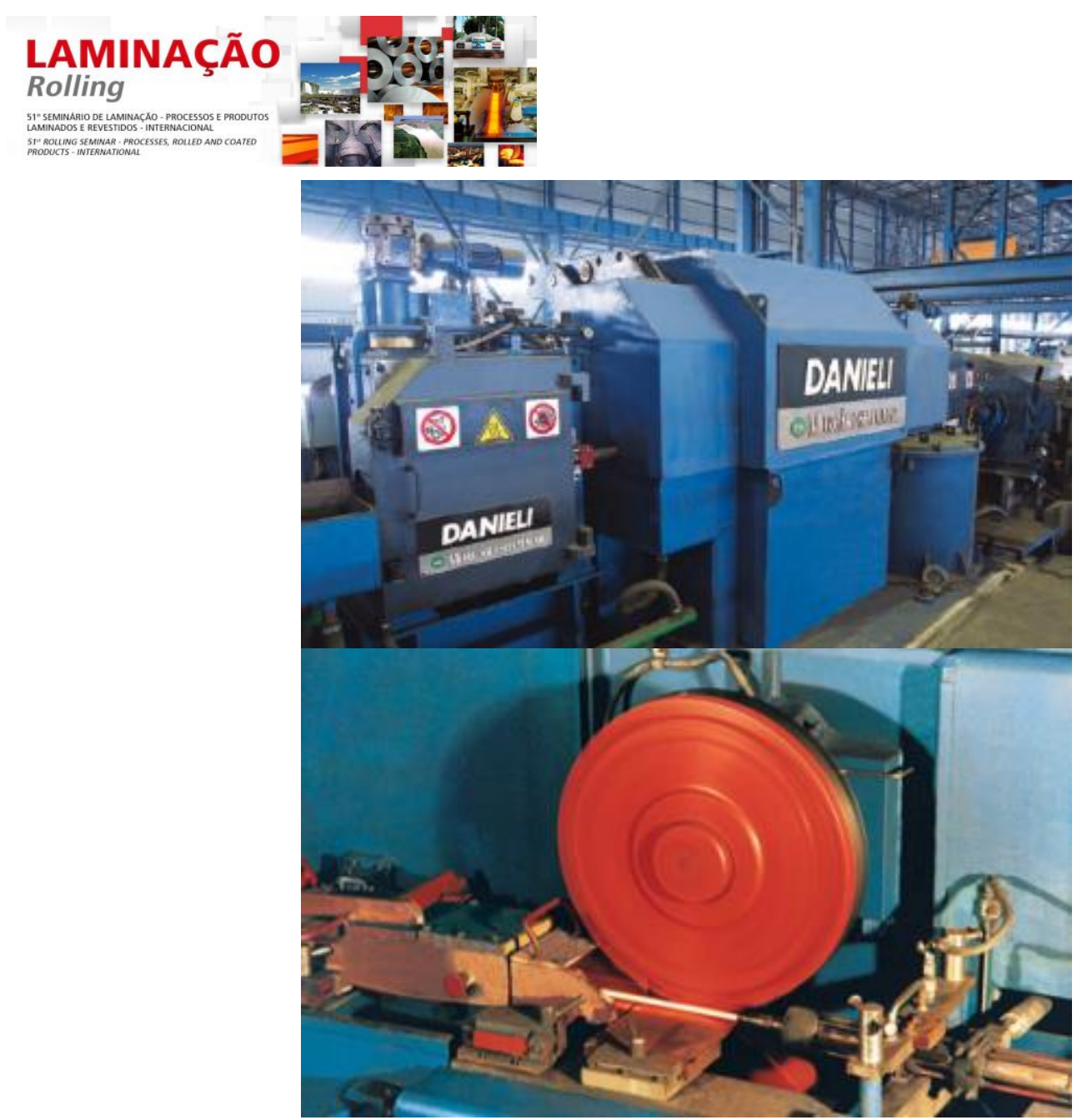

(a)

(b)

Figure 5. (a) HSS typical installation, (b) HSS blades holder and diverter detail

Since the metallurgical and technological characteristics for uncooled head and tail ends are totally uncontrolled, for $\mathrm{HC}$ grades it is essential to eliminate such portions. Moreover, the out-of-tolerance parts (e.g. tail overfill) must be cut because they cannot be directly processed in the downstream facilities. Otherwise, such trimming operations are required to be done in the hardware factories, thus brutally reducing material yield and overall productivity of drawing plants.

For these reasons it can be easily understood why in-line automatic high-speed cropping of wire rod represents the real answer to improve workplace safety as well as product yield and coil quality, and to reduce man power and, as a consequence, transformation costs. The compact High Speed Shear installed immediately before the Loop Laying Head (or before the $\mathrm{TMB}^{\circledR}$ in the latest generation wire rod mills) enables direct on-line automatic trimming of 5.0 to $26.0-\mathrm{mm}$-dia wire rod before coiling.

\subsection{LLH - Loop Laying Head}

It is a common target for wire rod mills to guarantee simultaneously a good coil pattern and a long pipe lifetime. Over recent years, with the increase of finishing rolling speeds, such need has become even more stringent, pushing laying head manufacturers and users to investigate new technological solutions and alternative materials.

In the specific case of HC grades, especially for small sizes, such need is crucial; as explained in the previous paragraphs, wire rod quality and uniformity of final

* Contribuição técnica ao $51^{\circ}$ Seminário de Laminação - Processos e Produtos Laminados e Revestidos, 28 a 31 de outubro de 2014, Foz do Iguaçu, PR, Brasil. 


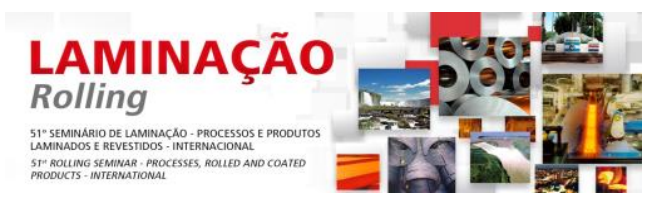

technological properties can be improved by achieving elevated rolling speeds. These very high rolling speeds (over $100 \mathrm{~m} / \mathrm{s}$, up to $120 \mathrm{~m} / \mathrm{s}$ ) imply head ends and especially tail ends formation problems if not properly controlled by mechanical and automation systems. Moreover, with these elevated rolling speeds, loops centering in the cooling conveyor becomes more difficult: such aspect is fundamental for $\mathrm{HC}$ grades because of the completion of the thermomechanical treatments (see next paragraph).

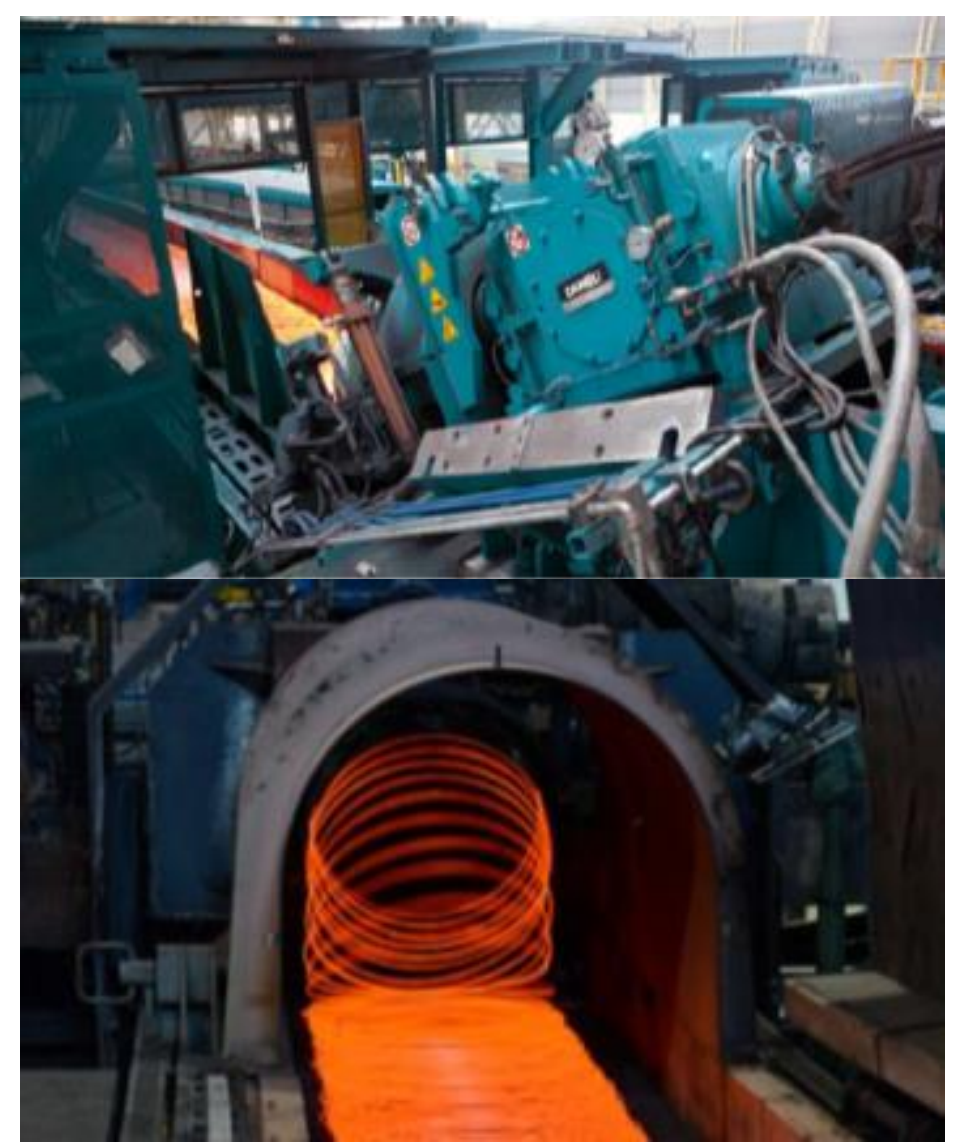

(a)

(b)

Figure 6. (a) Oil-film bearing laying head, (b) Ring pattern of a TurboLoop laying head while producing $\varnothing 5.5 \mathrm{~mm}$ SG3

Beyond the already well-known "oil-film bearing" patented design for rotor support that has led a new concept of stability and vibration-free operation, DMH has developed further patented solutions to achieve these targets:

- latest generation of LLH rotor: the advanced design, specifically studied using 3D kinetic-dynamic simulation, provides operation stability and optimisation of wearrate at high finishing speeds; the new design and material choice for the progressively-curved shape of LLH pipe give wire rod an ideal path, ensuring its constant contact with the inner wall along the whole pipe length and a consequent even wear distribution;

- "TurboLoop" (patent pending): it's a rotor designed in collaboration with Danieli R\&D, specifically developed for very high speeds ( $170 \mathrm{~m} / \mathrm{s}$ design speed and 150 $\mathrm{m} / \mathrm{s}$ in constant operation) that guarantees very few vibrations;

\footnotetext{
* Contribuição técnica ao $51^{\circ}$ Seminário de Laminação - Processos e Produtos Laminados e Revestidos, 28 a 31 de outubro de 2014, Foz do Iguaçu, PR, Brasil.
} 


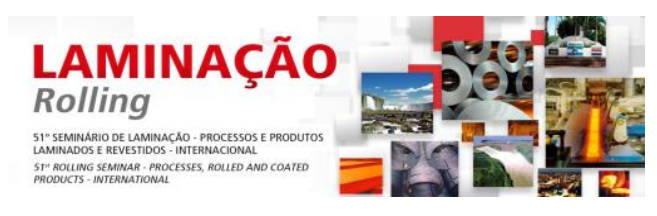

- LLHPlus 2-pipes rotor (patent pending): it's a newly design 2-pipes rotor alternative to the traditional single pipe rotor able to give big benefits in terms of coil pattern, surface quality, and head and tail ends formation.

\section{IN-LINE THERMOMECHANICAL TREATMENTS}

Over the recent years $\mathrm{HC}$ wire rod users have become more and more demanding in terms of overall quality of the product and, for specific application (e.g. tire cord), dedicated process routes must be applied to ensure the required performances.

Different technologies can be applied for the production of $\mathrm{HC}$ wire rod and the final $\mathrm{HC}$ patented wire [19], taking into consideration technological, economical, and environmental aspects.

The application of in-line heat treatments in rolling mills has deeply modified the process dimensioning approach for special steel wire rod plants that must combine simultaneously process flexibility, to increase the added value to the final product, and high productivity and material yield, to minimize production cost and environmental impact.

$\mathrm{DMH}$, partnering with some of the most important $\mathrm{HC}$ wire rod producers, has always been a forerunner in the definition of new process strategies and automation systems for the optimization of in-line heat treatments.

\subsection{DSC-Danieli Structure Control System: technological properties and scale optimization}

The control of rolling temperature is a key issue to achieve constant strain loads, optimum dimensional tolerances, elevate technological and metallurgical characteristics, improved product homogeneity, and adequate scale properties, both in terms of quality and quantity.

In Danieli DSC lines, a sequence of waterboxes is installed in strategic positions to manage rolling and coiling temperatures, allowing adequate time for bar self-tempering, thus ensuring minimum temperature difference between surface and core at wire rod blocks inlet. For HC grades, the optimal conditions are generally represented by what is commonly called "normalizing rolling" temperature range, finely controlled by the temperature close-loop system that must manage the high pressure water cooling nozzles.

$\mathrm{HC}$ grades are very sensitive to any improper control of rolling and coiling conditions that can lead to problems either substantial, affecting the final technological properties and the following drawing operations (e.g. density of pearlitic colonies), or merely esthetical, as the "red rust" aspect 22.

The structure of oxide scale of $\mathrm{HC}$ wire rod is composed of three layers, similarly to that formed on low-carbon steels and pure iron: wüstite $(\mathrm{FeO})$, magnetite $\left(\mathrm{Fe}_{3} \mathrm{O}_{4}\right)$ and hematite $\left(\mathrm{Fe}_{2} \mathrm{O}_{3}\right)$ from the inner to the outer layer. Nonetheless, for $\mathrm{HC}$ grades only two layers are substantially present, because of the low amount of hematite. The thickness of such scale is not-linearly proportional to temperature and time of oxidation: over $900^{\circ} \mathrm{C}$ and especially in the first 20 seconds of oxidation the growth of $\mathrm{FeO}$ is fast, then it is more linear, while the thickness of $\mathrm{Fe}_{3} \mathrm{O}_{4}$ remains approximately constant [21].

\footnotetext{
* Contribuição técnica ao $51^{\circ}$ Seminário de Laminação - Processos e Produtos Laminados e Revestidos, 28 a 31 de outubro de 2014, Foz do Iguaçu, PR, Brasil.
} 


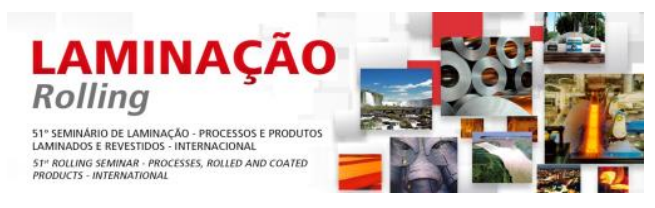

According to the needs of hardware factories, the scale quality and quantity is an important aspect to be controlled by a proper thermal treatment. For $\mathrm{HC}$ grades, either mechanical or chemical descaling can be required: in order to ensure optimal wüstite scale and to facilitate scale removal before drawing, elevated coiling temperatures $\left(>900^{\circ} \mathrm{C}\right)$ are suitable for mechanical descaling, while lower temperatures $\left(\sim 850^{\circ} \mathrm{C}\right)$ are used for chemical descaling, since in that case thin and dense scale is formed to reduce the metal loss and the pickling time. Anyhow, the best overall technological properties of the 2 cooling stages (forced water cooling during/after rolling and accelerated cooling in the cooling conveyor) must be investigated.

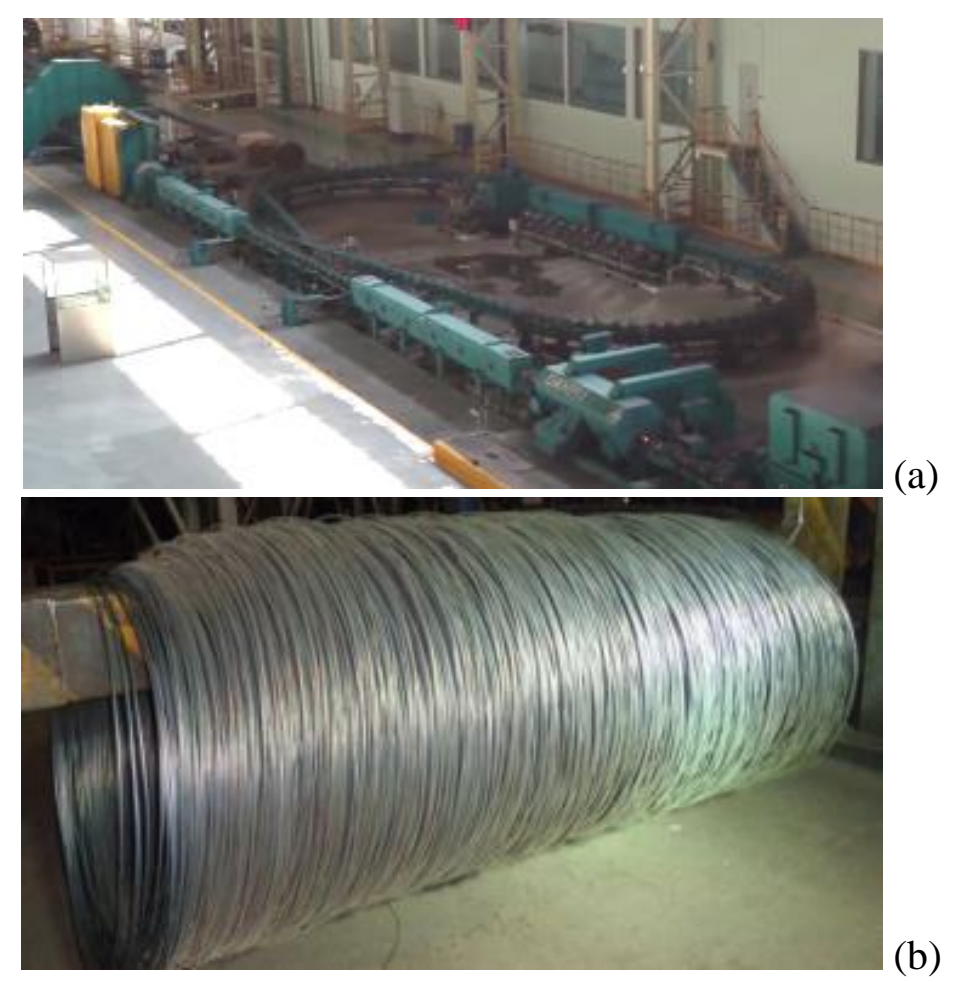

Figure 7. (a) Waterboxes installed in loop configuration in PFB area, (b) "Red rust" on Ø5.5mm 72D2: effect of different LLH temperatures on the same billet

For productivity, economic and environmental reasons, over the last years the requirements of wire rod suitable for mechanical descaling have been increased, even thanks to the improved technologies available for scale mechanical removal. For some applications a perfect scale-free surface is required, so chemical descaling is used. Alternative descaling technologies (e.g. plasma [22], ultrasonic cleaning [23], electrolytic cleaning in neutral media) have not proved yet to be fully comparable in terms of efficiency, even if big improvements have been recently done.

\subsection{CCW-Controlled Cooling Conveyor}

From the metallurgical point of view, the principal target for $\mathrm{HC}$ wire rod is to get the highest possible unresolvable pearlitic structure, thus minimizing presence of resolvable pearlite and structure-free cementite or ferrite. The presence of proeutectoid ferrite determines a ductility reduction in comparison with a fully pearlitic microstructure,

\footnotetext{
* Contribuição técnica ao $51^{\circ}$ Seminário de Laminação - Processos e Produtos Laminados e Revestidos, 28 a 31 de outubro de 2014, Foz do Iguaçu, PR, Brasil.
} 


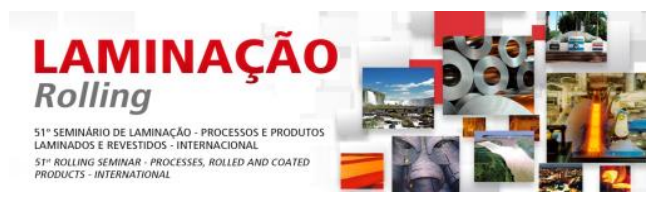

because of the higher possibility of crack initiation sites at ferritic-pearlitic interface. For this reason, the amount of proeutectoid ferrite has to be as limited as possible $(1 \div 2 \%)$, so the mechanical properties can generally be described by a Hall-Petch relation, defining tensile dependence from interlamellar spacing [24].

It is clear that the technological properties of the final wire rod are the effect of the whole production process, from scrap/ore selection, to steelmaking strategy, to casting technology, to billet preparation and reheating, to rolling temperature optimization (see previous paragraphs). That said, in the rolling mill area the core of $\mathrm{HC}$ wire rod production is represented by the temperature control of wire rod in the cooling conveyor. In this area, indeed, the steel phase transformations occur: depending on size and grade, the first 30 to 50 seconds of treatment in the CCW become strategical to get the best technological properties.

The best thermomechanical treatment for $\mathrm{HC}$ grades are determined by kinetic data on austenite decomposition, considering its dependence on chemical composition (C, Mn, Cr...) and cooling rate: in order to get the above mentioned technological properties, forced cooling conditions are required on CCW; such conditions are typically obtained by centrifugal fans installed under the conveyor (see Figure 8b).

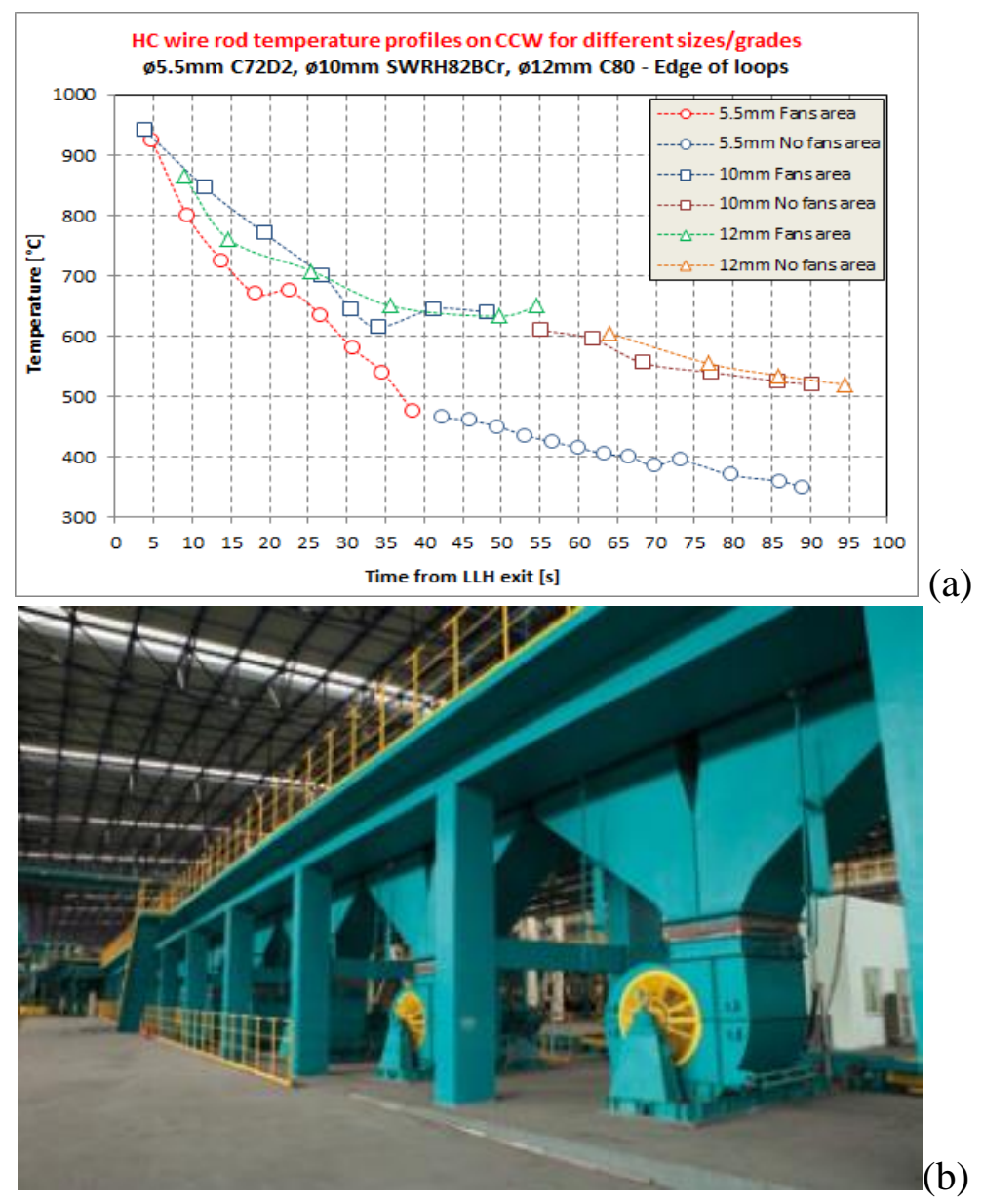

Figure 8. (a) Edge-of-loops temperature profile on CCW for different sizes and grades, (b) Centrifugal fans view

\footnotetext{
* Contribuição técnica ao $51^{\circ}$ Seminário de Laminação - Processos e Produtos Laminados e Revestidos, 28 a 31 de outubro de 2014, Foz do Iguaçu, PR, Brasil.
} 


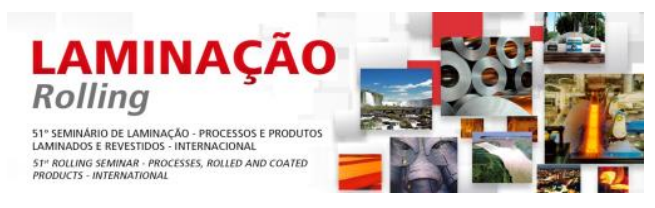

Through elevated cooling rates it is possible to increase the stability of supercooled austenite, thus decreasing the phase transformation temperature. In this way it is possible to improve the structural uniformity of the as-rolled wire rod, avoiding or reducing alloying addition (e.g. $\mathrm{Cr}, \mathrm{Mn}, \mathrm{V}$ ) to get the required tensile properties [25]; in the previous paragraphs it has been explained how an optimum balance of chemical compounds has to be found (e.g. Cr/Mn), not only for economic reasons, but also to avoid undesired phenomena that can affect the drawability.

To describe $\mathrm{HC}$ wire rod behavior on CCW, mathematical models incorporating both thermal and metallurgical evaluation need to be used [26], in order to overcome the limits of conventional TTT and CCT models. Such theoretical models can be employed for different cooling media (air, water, melt salts) and need an experimental validation of the overall heat-transfer coefficient (sum of convection and radiation contributions) [27].

To evaluate the microstructure evolution on CCW, dilatometric tests can be conducted to define the empirical coefficients of the modified Avrami equation, thus modeling the not-isothermal phenomena of wire rod cooling as a sequence of isothermal ones. Through the definition of final metallurgical structure and its correlation with steel composition and cooling rate, it is possible to predict final technological properties in terms of yields strength and ultimate tensile strength [28].

From the thermal point of view, for $\mathrm{HC}$ grades, more than for any other steel grade, two effects must be considered:

- wire rod thermal recover due to enthalpy of transformation;

- loops edge to center thermal difference due to different mass flow distribution [29].

It is fundamental to consider such aspects during the dimensioning stage of CCW, because they can affect the wire rod technological properties in terms of both absolute values and their variation (standard deviation). This is the reason why it is essential that the CCW be composed by independently motorized sections. These sections should be relatively short and the reference transport speed relatively high in order to obtain:

- elevated ring interspace to facilitate heat removal;

- frequent shifting of rings contact points (by introducing an overspeed between adjacent sections).

It is quite difficult to evaluate the effect of edge heat removal precisely by means of single spot pyrometers technology only, even with appropriate filtering of the signal. A more complete thermo-camera analysis can give an overall scenario to evaluate the extension of the phenomena. In figure 9, two thermo-camera snapshots on CCW are reported and heat retaining effect in edge of loops due to mass packing can be easily seen; with specific software for post processing image analysis, it is possible to go in detail and tune the setup of CCW to get the best performances.

\footnotetext{
* Contribuição técnica ao $51^{\circ}$ Seminário de Laminação - Processos e Produtos Laminados e Revestidos, 28 a 31 de outubro de 2014, Foz do Iguaçu, PR, Brasil.
} 

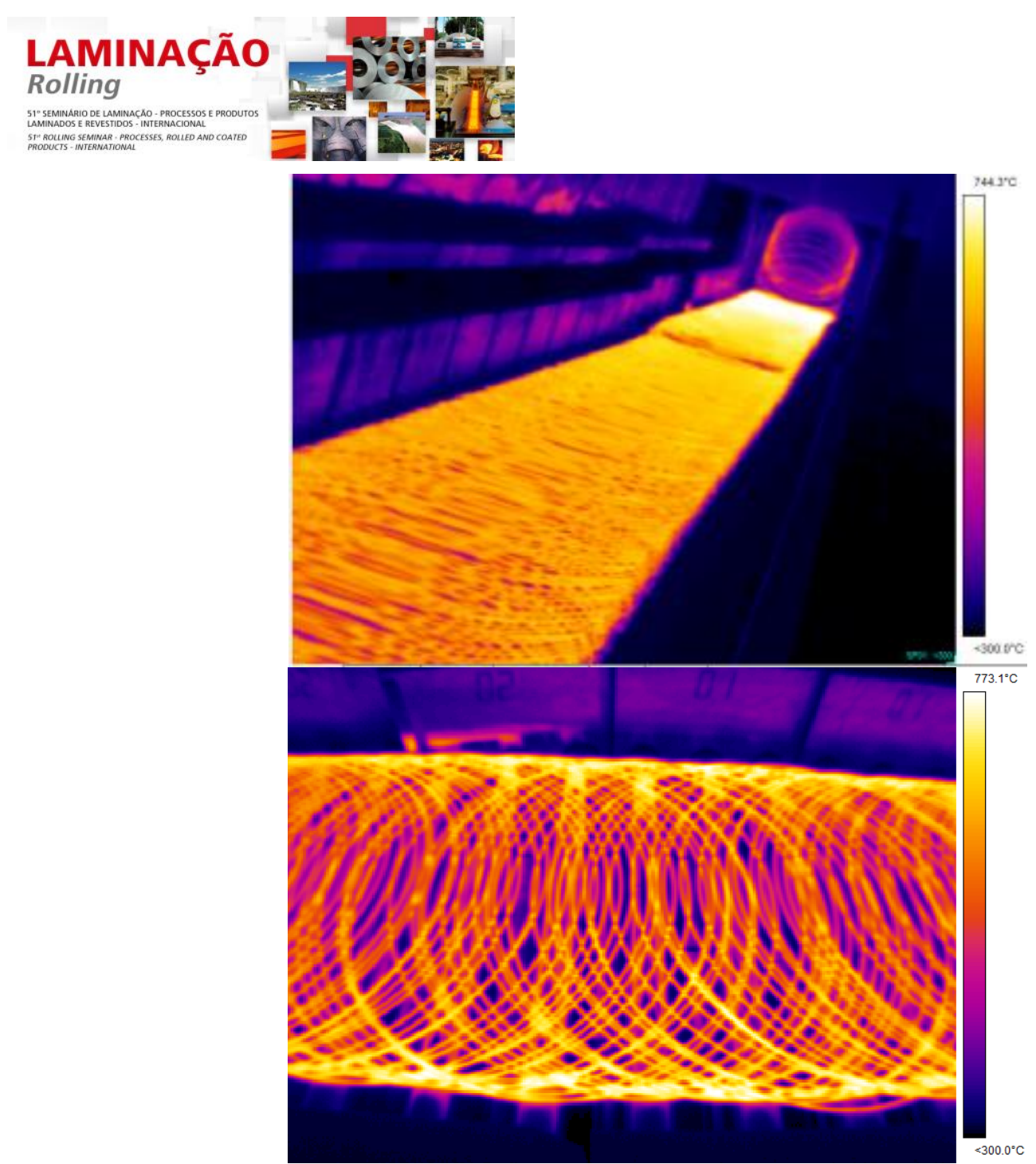

(a)

(b)

Figure 9. Thermo-camera snapshots on CCW: (a) LLH view for grade AISI 1006, (b) example of edge/centre temperature profile on CCW for grade AISI 1065.

In order to compensate this thermal distribution, several approaches can be used. For air cooling systems, mechanical devices are required to control flow distribution, directing the air where it is effectively required. In figure $10 \mathrm{a}$, pathlines of velocity magnitude is reported: by means of fans internal dumpers, it is possible to maximize the air flow towards the edge of loops, in proportional way with mass flow distribution.

From the fans dimensioning point of view, it is very important to consider simultaneously process flexibility, productivity requirements and steel grades specific microstructural needs. The best fan motor choice in terms of power (related to air flow and pressure requirements) and regulation (single polarity, double polarity, inverter...), must indeed consider the whole range of $\mathrm{HC}$ sizes and grades of product mix.

Such level of control is absolutely required for the most critical $\mathrm{HC}$ grades as metal cord and spring steel, since a fine tuning of thermomechanical treatment on CCW is required to obtain a proper sorbite-like pearlite microstructure (see figure 10b). This microstructure is the most suitable to get significant energetic/economic and environmental benefits [30]: on the one side, the improved microstructure can lead to the elimination of some intermediate processes before drawing (e.g. for $1.55 \mathrm{~mm}$ bronzed wire production) and to the improvement of roughing and intermediate stages in

* Contribuição técnica ao $51^{\circ}$ Seminário de Laminação - Processos e Produtos Laminados e Revestidos, 28 a 31 de outubro de 2014, Foz do Iguaçu, PR, Brasil. 


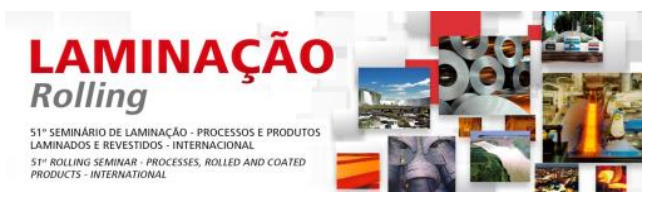

wire production, thanks to the wire rod enhanced plastic properties; on the other side, the possibility to avoid off-line lead patenting process and the related problems of baths management and disposal for the production of superhigh-strength wire and metal cord ensure an eco-friendly approach for $\mathrm{HC}$ wire production.

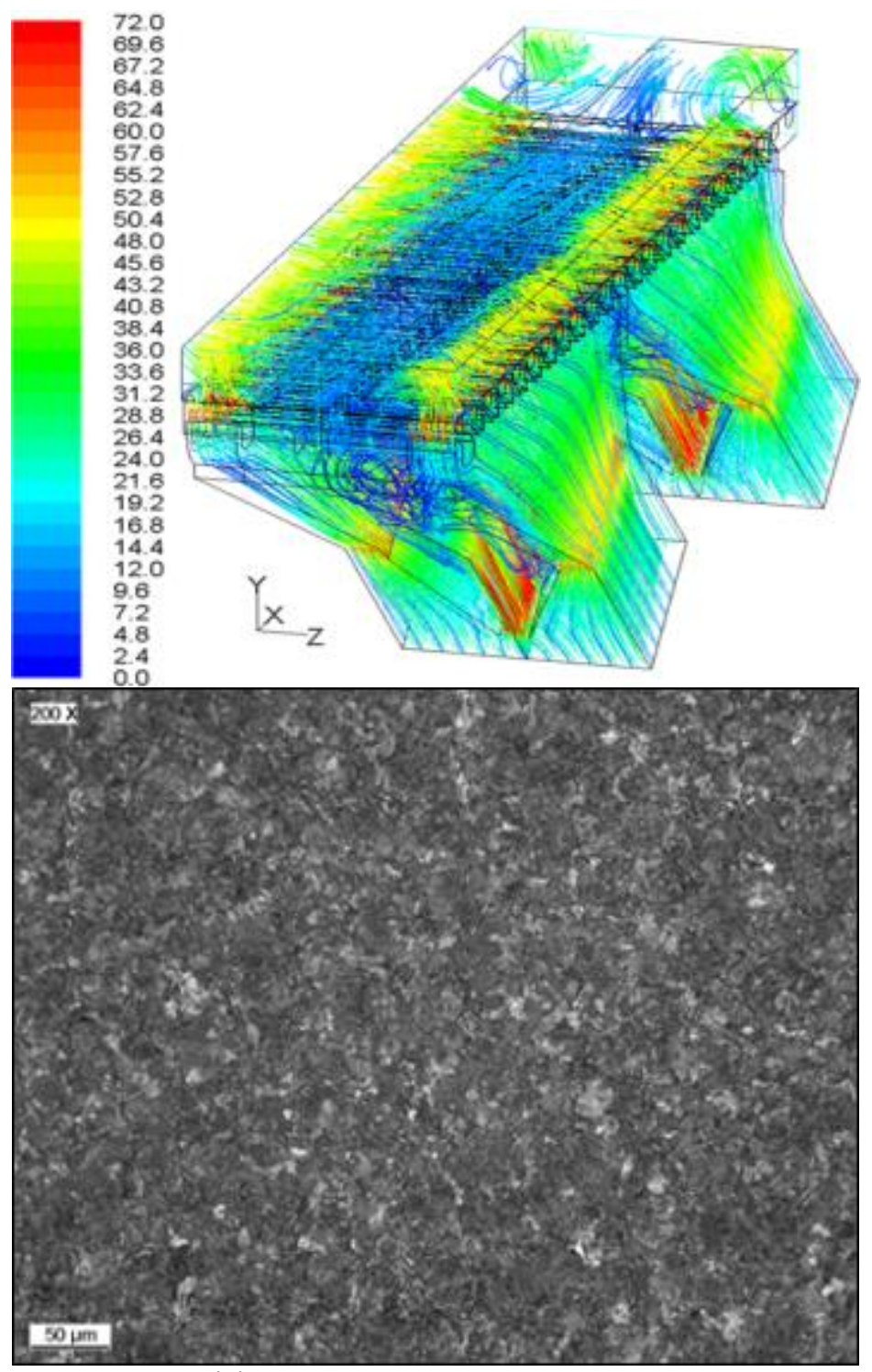

(a)

(b)

Figure 10. (a) Velocity magnitude $(\mathrm{m} / \mathrm{s})$ pathlines output, (b) Sorbitic microstructure of CCW thermomechanically treated SWRH 82A

\subsection{EDC-Easy Drawing Continuous}

Besides the technologies previously reported, a limit of forced air cooling systems still exists and it is represented by the cooling media itself, especially when fast removal of heat generated by the metallurgical transformation is required: even increasing air flow, a plateau in cooling capacity is reached.

* Contribuição técnica ao $51^{\circ}$ Seminário de Laminação - Processos e Produtos Laminados e Revestidos, 28 a 31 de outubro de 2014, Foz do Iguaçu, PR, Brasil. 


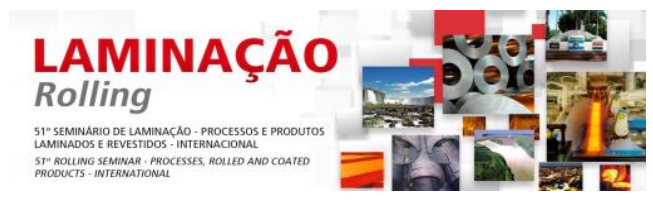

To overcome such limit, Danieli has developed the EDC (Easy Drawing Continuous), a boiling water in-line patenting system, specifically developed for tire cord applications. Several customers of Danieli's have established a joint venture with some of the most renowned tire cord producers to promote this technology.

The EDC shiftable line comprises a roller-type cooling conveyor with a process water system. The system consists of two sections, one process tank (upper) and one evacuating tank (lower); the first one is provided with the roller conveyor which transfers the wire rod through the tank for cooling according to selected cooling mode (which depends on steel grade and wire rod size). In order to allow the maximum flexibility, the system has been designed so that it can shift sideways from in-line to off-line position in order to treat all the possible steel grades ranges and sizes with EDC or conventional CCW.

The EDC can be used as an alternative to the fans cooling to achieve in-line patenting of $\mathrm{HC}$ grades using boiling water without any additives. The process can be described as composed of four stages (figure 11):

- film boiling incubation stage: as soon as the wire rod enters the hot water tank it is strongly cooled in a short time;

- film boiling stage: the wire rod is enveloped by a steam film, which acts as an insulator, simulating the ideal conditions for the patenting;

- nucleate boiling stage: under a critical temperature value, the steam film breaks and steam bubbles are generated, thus increasing dramatically the cooling rate;

- convection stage: when leaving the process water tank, the wire rod is transported on CCW and is cooled by natural or forced air, thus decreasing the cooling rate

Compared to other methods, the EDC process can give a better sorbitic microstructure (see previous paragraphs) and an enhanced cold drawability. Improved and more uniform mechanical properties can be reached, due to the effective cooling in hot water and to the independence from other environmental factors (e.g. performance fluctuation due to air temperature or humidity), and a more precise control of grain growth and scale formation is granted, thanks to the extreme flexibility of the control parameters: LLH exit temperature, process water temperature, water basin level, CCW reference speed, secondary cooling fans setup, etc.

* Contribuição técnica ao $51^{\circ}$ Seminário de Laminação - Processos e Produtos Laminados e Revestidos, 28 a 31 de outubro de 2014, Foz do Iguaçu, PR, Brasil. 

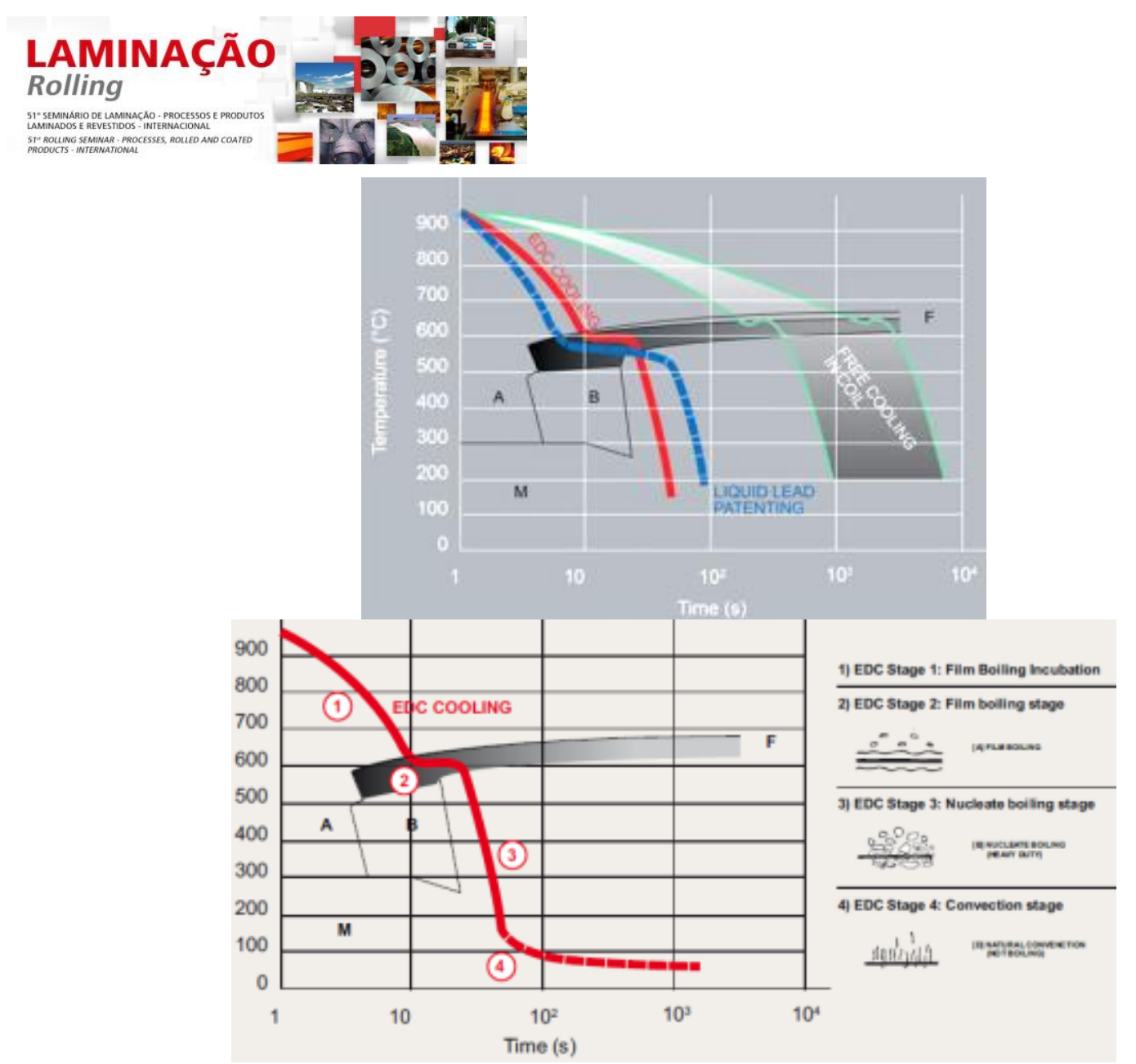

(a)

(b)

Figure 11. (a) HC patenting process comparison, (b) EDC process description

As well as for CCW, for EDC process mathematical models can be used to help operative routes definition [31]. Also in this case, thermal and metallurgical models must be integrated to describe the effects of different parameters and their complex correlation, in order to optimize the process parameters thus guaranteeing the required technological properties of wire rod [32-35].

\section{PROCESS SIMULATION}

\subsection{DLPP ${ }^{\circledR}$ - Danieli Long-products Properties Predictor}

Today's demand in terms of productivity and quality in hot rolling mills require continuous analysis of processes and equipment. To reduce risks, time and cost in projects for the introduction of new products and the managing of new equipment, process simulators can be very useful tools for $\mathrm{HC}$ wire rod producers, since rolling mill control and process optimization play a fundamental role.

DLPP $^{\circledR}$ software has been designed as a quality management tool for the rolling process; a computer model pre-calculates rolling and cooling processes/technologies performance, predicts the microstructure evolution and final mechanical properties of hot rolled wire rods and bars [36]. DLPP ${ }^{\circledR}$ enables to predict temperatures profile for long products during rolling and final cooling for several steel grades: low, medium and high carbon steels, low and medium alloyed steels, spring tool and bearing steels, free

* Contribuição técnica ao $51^{\circ}$ Seminário de Laminação - Processos e Produtos Laminados e Revestidos, 28 a 31 de outubro de 2014, Foz do Iguaçu, PR, Brasil. 


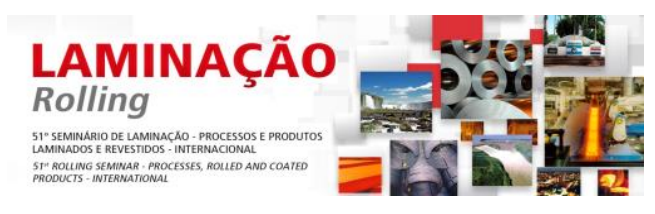

cutting steels. A special tool allows to predict the thermal evolution for austenitic, martensitic, and ferritic stainless steel, as well as for Ti-alloys and Ni-alloys.

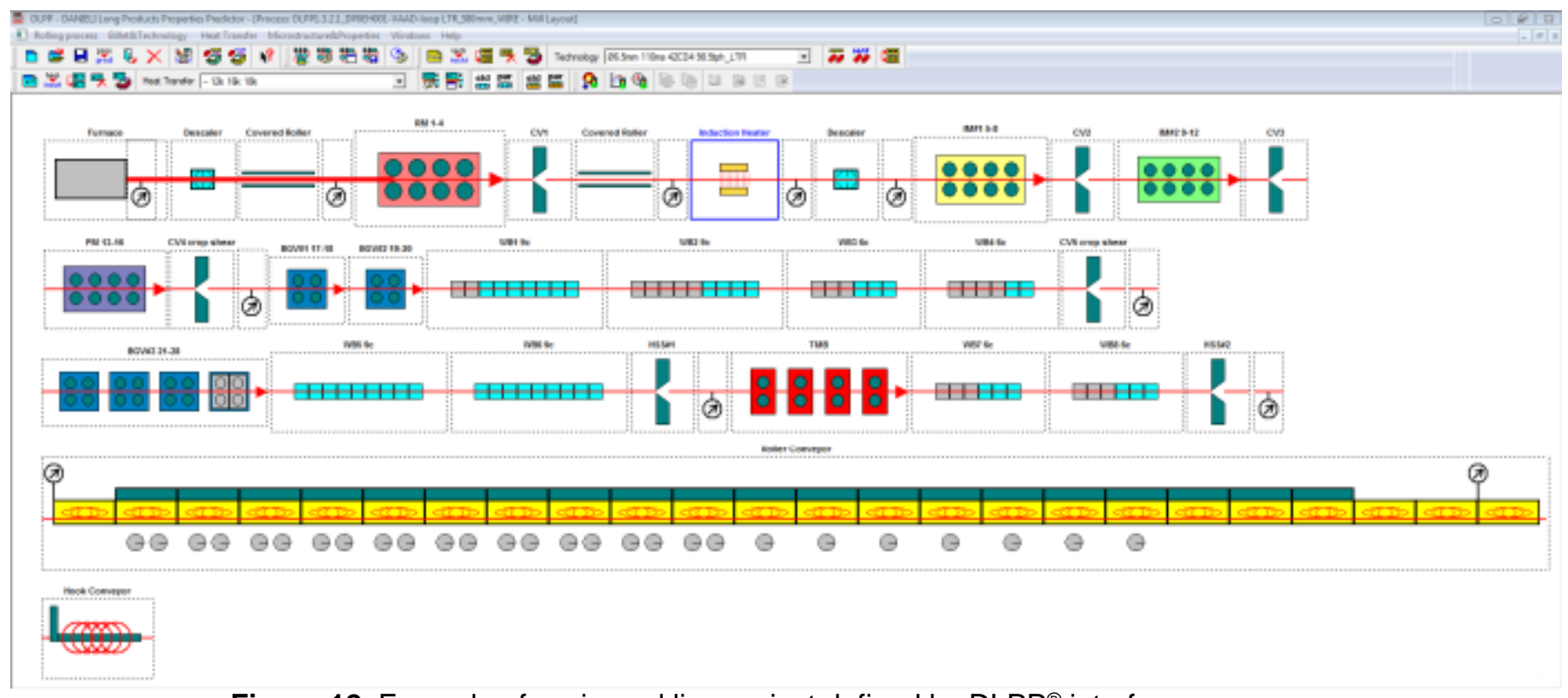

Figure 12. Example of a wire rod line project defined by DLPP ${ }^{\circledR}$ interface

The software can be applied to develop both specific studies for existing plants (e.g. revamping projects, steel grade upgrading), and to optimize new plants dimensioning. By means of $\mathrm{DLPP}^{\circledR}$ it is possible to evaluate the thermal behaviour along the whole length of a modern rolling mill, from CCM exit to finishing areas (see also figure 4). It is possible to simulate cold and hot charging process routes, as well as inductive heating or thermal behaviour inside reheating furnaces, with the definition of all the reheating patterns (pre-heating, heating, soaking). Moreover, the final microstructure and mechanical properties of hot rolled wire rods and bars after rolling and inline cooling can be predicted. By means of a specific module, DLPP ${ }^{\circledR}$ is able to include all the technological devices of a modern rolling mill with the relative distances and specific process functions. It is possible to set all the main process parameters that may affect plant productivity and material behavior during rolling:

- starting billet: dimensions, temperature profile (along cross section and along length), specific chemical composition, scale loss due to RHF;

- interbillet interval and any billet waiting or handling time;

- shears' crops along the mill;

- technological distances between each device;

- rolls/rings dimensions, elongations and speeds along the line (including multistrand rolling technology);

- wire rod CCW setup: speed, slow cooling, air/fan cooling, EDC cooling;

- in-line heat treatments during and after rolling: water or air cooling, thermal insulating devices, tempering/annealing furnaces for both in-line and off-line treatments.

According to chemical composition and microstructure parameters of deformed austenite after rolling (grain size, re-crystallized fracture, retained strain), it is possible to

* Contribuição técnica ao $51^{\circ}$ Seminário de Laminação - Processos e Produtos Laminados e Revestidos, 28 a 31 de outubro de 2014, Foz do Iguaçu, PR, Brasil. 


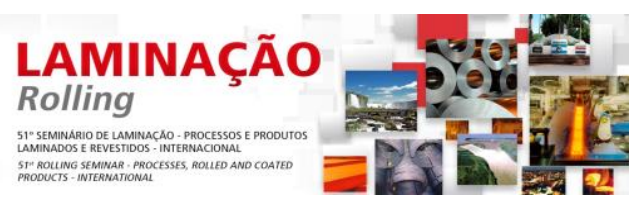

predict final microstructure shares by crossing the cooling curves with the generated HCT (Hybrid Cooling Transformation) diagrams. Final mechanical properties (Hardness, Tensile and Yield) can lastly be estimated by multi-parametric regression analysis.

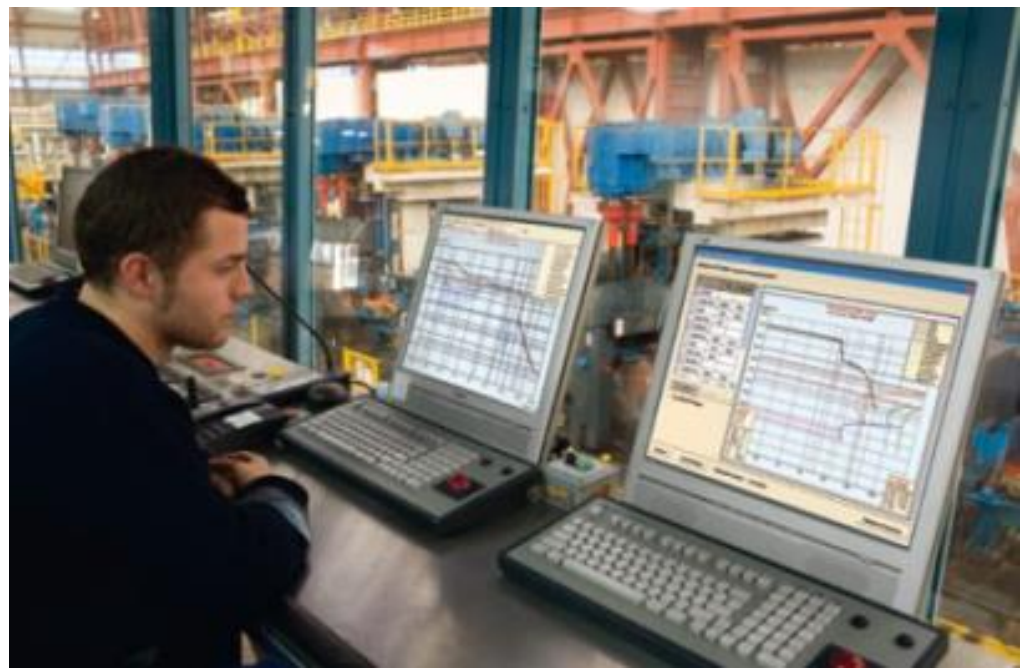

(a)

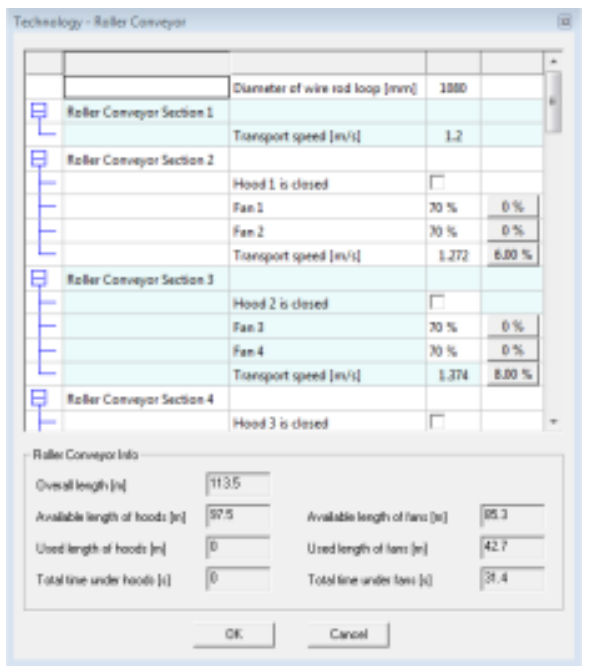

(b)

Figure 13. DLPP ${ }^{\circledR}$ examples: (a) on-site $D L P P^{\circledR}$ installation in a modern wire rod mill, (b) working page of CCW for the setup of a $\mathrm{HC}$ grade wire rod

\section{CONCLUSIONS}

The production of high carbon steel wire rod is characterized by an increasing demand in terms of metallurgical and technological quality, overall productivity, and rolling flexibility. The complete process route must be optimized according to the specific application of the wire rod and to the precise requirements of the final customer. The combination of proven technology and experience with strong, long-lasting relationships between steel producers and machinery suppliers is the key factor to success.

The implementation of in-line thermo-mechanical treatments during and after the rolling process is crucial to obtain the technological added value of the final product. In cooperation with some of the biggest special steel producers in the world, Danieli has developed a deep multidisciplinary and integrated competence in this field.

Danieli's technology, experience, know-how and farsighted approach undoubtedly represent a perfect combination to achieve cutting edge results in the production of high carbon steel wire rod.

\section{REFERENCES}

1 Bell A, Hobson S, Wilkinson, O'Connor C, Sefton S. Development of ultra high-strength wire for offshore applications. Wire Journal International, 2008; 41(5): 78-88.

2 Sychkov AB, Zhigarev MA, Zhukova YS, Kucherenko OL, Repin IV. Production of wire rod for high-strength reinforcing cord. Steel in Translation, 2010; 40(1): 78-81.

3 Parusov VV, Sychkov AB, Derevyanchenko IV, Perchatkin AV, Parusov EV, Zhigarev MA. High-carbon wire rod made of steel microalloyed with vanadium. Metallurgist, 2004; 48(1112): 618-625.

\footnotetext{
* Contribuição técnica ao $51^{\circ}$ Seminário de Laminação - Processos e Produtos Laminados e Revestidos, 28 a 31 de outubro de 2014, Foz do Iguaçu, PR, Brasil.
} 


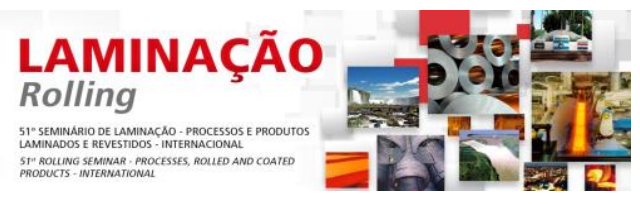

4 Tarui T, Takahashi J, Tashiro H, Maruyama N, Nishida S. Microstructure Control and Strengthening of High-carbon Steel Wires. Nippon Steel technical report, 2005; 91: 56-61

5 Saltuk VN, Terskikh DS. Manufacture of rebar from sorbitized wire rod. Steel in Translation, 2012; 42(3): 257-260.

6 Dhua SK, Singh CD, Ray A. Metallurgical investigation into the causes of premature failure of high-carbon steel wire rods during hot rolling. Journal of Failure Analysis and Prevention, 2005; 5(4): 67-73.

7 Sychkov AB, Zhigarev MA, Perchatkin AV, Berkovskii VA, Krulik Al. High-carbon wire rod made of high-chromium steel. Metallurgist, 2006; 50(3-4): 183-188

8 Parusov VV, Derevyanchenko IV, Sychkov AB, Nesterenko AM, Parusov ÉV, Zhigarev MA. Ensuring high quality indices for the wire rod used to make metal cord. Metallurgist, 2005; 49(11-12): 439-448.

9 Lutsenko VA, Bobkov PA, Rad'kova IN, Lutsenko OV, Chernichenko VG.

Thermomechanically treated high-carbon wire rod for high-tension wire. Steel in Translation, 2012; 42(11): 794-796.

10 Filho CJC, Mansur MB, Modenesi PJ, Gonzalez BM. The effect of hydrogen release at room temperature on the ductility of steel wire rods for pre-stressed concrete. Materials Science and Engineering A, 2010; 527(18-19): 4947-4952.

11 Chanda T. Reverse ageing in hot-rolled high-carbon steel wire rod, Journal of Materials Science, 2010; 45(22): 6068-6074.

12 Yamasaki S, Nishida S, Hirakami D, Tauri T. Evaluation of hydrogen embrittlement susceptibility of PC wires. Wire Journal International, 2009; 42(5): 58-62.

13 Patwari K, Pradhan N, Banerjee N, Pal BR, Sarkar SR, Mukhopadhyay B, Ray SK, Basu DS. Technological Intervention for Production of High Carbon Billets. Materials \& Manufacturing Processes, 2010; 25(1-3): 111-117.

14 Ricci MG. Sistemi di controllo, modelli matematici e automazione. Forni di riscaldo per prodotti lunghi: come aumentare la produttività - Associazione Italiana di Metallurgia Conference, Brescia, Italy, December 2013

15 Taurino A. Europe's most technologically advanced wire rod mill for voestalpine in Donawitz. DaNews, 2014; 169: 46-47.

16 Diasparro A, Redolfi N, Fabbro C, Taurino A, Mestroni A. Technical Achievements in WireRod Production: Technologies and Processes of the $\mathrm{H}^{3}$ system. Rolling 2013, 9th International Rolling Conference, 6th European Rolling Conference 2013, Venezia, Italy, June 2013

17 Fabbro C, Redolfi N, Celano A, Taurino A. Stainless Steels Long Products - Danieli references and know how. The Fifth Baosteel Biennial Academic Conference, Shanghai, P.R. China, June 2013

18 Lutsenko VA, Bobkov PA, Kirilenko OM, Gritsaenko VI, Lutsenko OV. Thermomechanical treatment of high-carbon wire rod in the 150 high-speed wire mill at Belorussian Metallurgical Plant. Steel in Translation, 2012; 42(1): 78-80.

19 Tyl TW. Steel patenting technology in the manufacture of steel tire cord. Wire Journal International, 2008; 41(10): 80-87.

20 Sychkov AB, Zhigarev MA, Zhukova SY, Perchatkin AV, Gritsaenko VI. Ensuring complete scale removal from wire rod before drawing. Steel in Translation, 2013; 43(2): 73-78.

$21 \mathrm{Hu}$ XJ, Zhang BM, Chen SH, Fang F, Jiang JQ. Oxide Scale Growth on High Carbon Steel at High Temperatures. Journal of iron and steel research, International, 2013; 20(1): 47-52.

22 Rogelj I. Plasma: a clean and cost-effective alternative to chemical and heat treatment", Wire Journal International, 2008; 41(6): 72-78.

23 Svonni J-H. Hot Rolled Wire Descaling. Master's Thesis in Applied Physics, Department of Materials and Manufacturing Technology, Chalmers University of Technology, Goteborg, Sweden 2012, pp. 4-31

\footnotetext{
* Contribuição técnica ao $51^{\circ}$ Seminário de Laminação - Processos e Produtos Laminados e Revestidos, 28 a 31 de outubro de 2014, Foz do Iguaçu, PR, Brasil.
} 


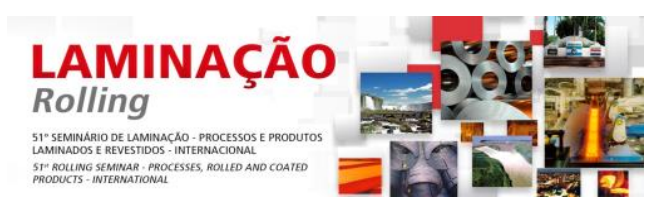

24 Kazeminezhad M, Taheri AK. The effect of controlled cooling after hot rolling on the mechanical properties of a commercial high carbon steel wire rod. Materials and Design, 2003; 24(6): 415-421.

25 Lutsenko VA, Matochkin VA, Khudole Yu L, Chernichenko VG, Lutsenko OV. Influence of Thermomechanical Treatment and Alloying on the Properties of High Carbon wire rod, Steel in Translation, 2010; 40(9): 853-856.

26 P.K. Agarwal, Brimacombe JK. Mathematical model of heat flow and austenite-pearlite transformation in eutectoid carbon steel rods for wire. Metallurgical Transactions $B, 1981$; 12B(1): 121-133.

27 Campbell PC, Hawbolt EB, Brimacombe JK. Microstructural Engineering Applied to Controlled Cooling of Steel Wire Rod: Part I. Experimental Design and Heat Transfer, Metallurgical Transactions A, 1991; 22A: 2769-2778.

28 Campbell PC, Hawbolt EB, Brimacombe JK. Microstructural Engineering Applied to Controlled Cooling of Steel Wire Rod: Part II. Microstructural Evolution and Mechanical Properties Correlations. Metallurgical Transactions A, 1991; 22A: 2779-2790.

29 Campbell PC, Hawbolt EB, Brimacombe JK. Microstructural Engineering Applied to Controlled Cooling of Steel Wire Rod: Part III. Mathematical Model-Formulation and Predictions, Metallurgical Transactions A, 1991; 22A: 2791-2805.

30 Peretyagina EA, Lutsenko VA, Vengura AV, Bobkov PA, Savinkov VV. Energy-saving sorbitization of high-carbon wire rod in the 150 mill", Steel in Translation, 2013; 43(5): 321324.

31 Zufia A, Llanos JM. Mathematical Simulation and Controlled Cooling in an EDC Conveyor of a Wire Rod Rolling Mill”, ISIJ International, 2001; 41(10): 1282-1288.

32 Matochkin VA. Heat Treatment and Surface Preparation of High-Carbon Wire Rod in Drawing, Steel in Translation, 2007; 37(6): 540-542.

33 Pikos B, Pilarczyk JW, Golis B, Wludzik R, Krnac J. Effect of drawing in sigmoidal, concave, convex and conical dies on mechanical properties of high carbon steel wires, International Wire \& Cable, Bologna, Italy, November 2007

34 Komori K. Evolution of void volume fraction for simulating inner fracture defects related to in drawing of high-carbon steel wire rods, Theoretical and Applied Fracture Mechanics, 2008; 50(2): 157-166.

35 Shaojun C, Cheng X, Dan Z, Guozhen Z, Xiaofeng C. Test and evaluation of tempered bead wire in the cold drawing process. International Wire \& Cable, Bologna, Italy, November 2007

36 Cimolino M, Fabbro C. Latest improvements for quality and process control in the new BARIN-COIL lines, AISTech 2014 Iron \& Steel Technology, Indianapolis IN, USA, May 2014

* Contribuição técnica ao $51^{\circ}$ Seminário de Laminação - Processos e Produtos Laminados e Revestidos, 28 a 31 de outubro de 2014, Foz do Iguaçu, PR, Brasil. 